\title{
Microdialysis: the Key to Physiologically Based Model Prediction of Human CNS Target Site Concentrations
}

\author{
Yumi Yamamoto, ${ }^{1}$ Meindert Danhof, ${ }^{1}$ and Elizabeth C. M. de Lange ${ }^{1,2}$
}

Received 22 November 2016; accepted 25 January 2017; published online 9 March 2017

\begin{abstract}
Despite the enormous research efforts that have been put into the development of central nervous system (CNS) drugs, the success rate in this area is still disappointing. To increase the successful rate in the clinical trials, first the problem of predicting human CNS drug distribution should be solved. As it is the unbound drug that equilibrates over membranes and is able to interact with targets, especially knowledge on unbound extracellular drug concentration-time profiles in different CNS compartments is important. The only technique able to provide such information in vivo is microdialysis. Also, obtaining CNS drug distribution data from human subjects is highly limited, and therefore, we have to rely on preclinical approaches combined with physiologically based pharmacokinetic (PBPK) modeling, taking unbound drug CNS concentrations into account. The next step is then to link local CNS pharmacokinetics to target interaction kinetics and CNS drug effects. In this review, system properties and small-molecule drug properties that together govern CNS drug distribution are summarized. Furthermore, the currently available approaches on prediction of CNS pharmacokinetics are discussed, including in vitro, in vivo, ex vivo, and in silico approaches, with special focus on the powerful combination of in vivo microdialysis and PBPK modeling. Also, sources of variability on drug kinetics in the CNS are discussed. Finally, remaining gaps and challenges are highlighted and future directions are suggested.
\end{abstract}

KEY WORDS: brain extracellular fluid (brain $\left.{ }_{\mathrm{ECF}}\right)$; central nervous system (CNS); cerebrospinal fluid (CSF); mastermind research approach; physiologically based pharmacokinetic (PBPK) model.

\section{INTRODUCTION}

There is a huge unmet medical need for central nervous system (CNS) disease therapies because of the growing of chronic and complex diseases associated with aging. However, development of CNS drugs is one of the most challenging tasks for the pharmaceutical industry (1). Actually, drug development for CNS drugs has suffered a higher attrition rate compared to that of other therapeutic areas drugs; it has been reported that only around $8-9 \%$ of CNS drugs that entered phase 1 were approved to launch (2). And around $50 \%$ of the attrition of potential CNS drugs has resulted due to a lack of efficacy and

The original version of this article was revised: Figure 3 in the PDF and electronic versions of the published article contains formatting errors caused by the typesetter.

\footnotetext{
${ }^{1}$ Division of Pharmacology, Cluster Systems Pharmacology, Leiden Academic Centre for Drug Research, Leiden University Gorlaeus Laboratories, Einsteinweg 55, 2333 CC, Leiden, The Netherlands.

${ }^{2}$ To whom correspondence should be addressed. (e-mail: ecmdelange@lacdr.leidenuniv.nl)
}

safety issues in phase $2(2,3)$. Knowledge of human CNS drug concentrations forms the basis for understanding exposureresponse relationships; therefore, the lack of appropriate consideration of these target concentrations is one of the factors contributing to this high degree of attrition.

Obtaining the target site concentrations of CNS drugs is not straightforward because plasma concentrations do not adequately reflect CNS exposure, primarily due to the presence of the blood-brain barrier (BBB) and the bloodcerebrospinal fluid barriers (BCSFB), and additional specific physiological characteristics of the CNS. Furthermore, significant variation in the rate and extent of mechanisms that govern target site pharmacokinetics (PK), target engagement, and signal transduction is known to exist, due to differences in system conditions such as species, gender, genetic background, age, diet, disease, and drug treatment (4). Moreover, with regard to CNS drug action, there is a lack of sufficiently established clinical biomarkers and proof-of-concept (5). Thus, it is clear that there is a need for more predictive approaches. These predictive approaches have to be interconnected to the system conditions and must be performed using adequate (including bound and unbound drug) 
concentrations. Also processes should preferably not be studied in isolation and then combined, but instead studied in conjunction with each other as this will provide insight about the interdependencies of these processes (4). Since measurements on CNS target site concentration in the clinical setting are highly restricted, we have to develop an approach based on integrated preclinical data that is translatable to human.

Even though drug properties have been investigated well, information of CNS system properties (CNS physiology and biochemistry) is sparse and has a large variability. CNS pharmacokinetics of drugs is determined by their interaction. System properties depend on the condition of the system, which means that we have to use approaches to distinguish between system and drug properties, as this would allow us to translate the model to other species and also other disease conditions, by using physiologically based pharmacokinetic (PBPK) modeling.

Currently, many more or less complex semi-PBPK models have been published for CNS drug distribution. At present, four preclinical translational models have been validated with human CNS concentration profiles (6-9). In these models, however, the parameters were estimated using in vivo data to describe CNS distribution of individual drug in animals. Ultimate goal of the PBPK modeling is to build a generic PBPK model in which the parameters are derived from in vitro and/or in silico data. To achieve this, in vivo data is needed to validate the generic PBPK model. Furthermore, an investigation is needed on the relationship between drug physicochemical properties and CNS distribution.

In this review, system properties and small-molecule drug properties that together govern CNS drug distribution are summarized, followed by currently available approaches on prediction of CNS pharmacokinetics, including in vitro, in vivo, ex vivo, and in silico approaches, with special focus on the powerful combination of in vivo microdialysis and PBPK modeling. Also, sources of variability on drug kinetics in the CNS are discussed. Finally, remaining gaps and challenges will be discussed and future directions will be provided.

\section{INTERACTION BETWEEN CNS SYSTEM AND DRUG PROPERTIES}

Many CNS system properties and drug specific properties are known to influence drug kinetics in the brain, as shown in Fig. 1. Here, we focus on the relevant factors from each that contribute to the drug kinetics and summarize their function.

\section{CNS SYSTEM PROPERTIES}

\section{Physiological Compartments, Flows, and pH}

The CNS is a complex system composed of many physiological components and flows (Fig. 2): Physiological compartments are the BBB, the BCSFB, brain extracellular

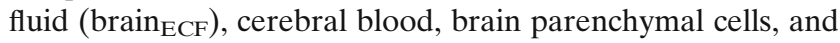
the cerebrospinal fluid (CSF) in the ventricles, the cisterna magna, and the subarachnoid space (4). There are $\mathrm{pH}$ differences among the compartments (10-16). Then, there are the CNS fluid flows that include the cerebral blood flow $(\mathrm{CBF})$, brain ${ }_{\mathrm{ECF}}$ bulk flow, and CSF flow. All relevant physiological parameter values are summarized in Table I.

\section{Active Transporters}

The localization of transporters and their expression level are also important factors to determine drug distribution in the brain. Transporters are present at the BBB and at the BCSFB, also on the membrane of brain parenchyma. Active transporters on the $\mathrm{BBB}$ and $\mathrm{BCSFB}$ consist of facilitated transport and ATP-dependent transport. The solute carrier (SLC) family, such as organic aniontransporting polypeptide (OATP) and organic anion
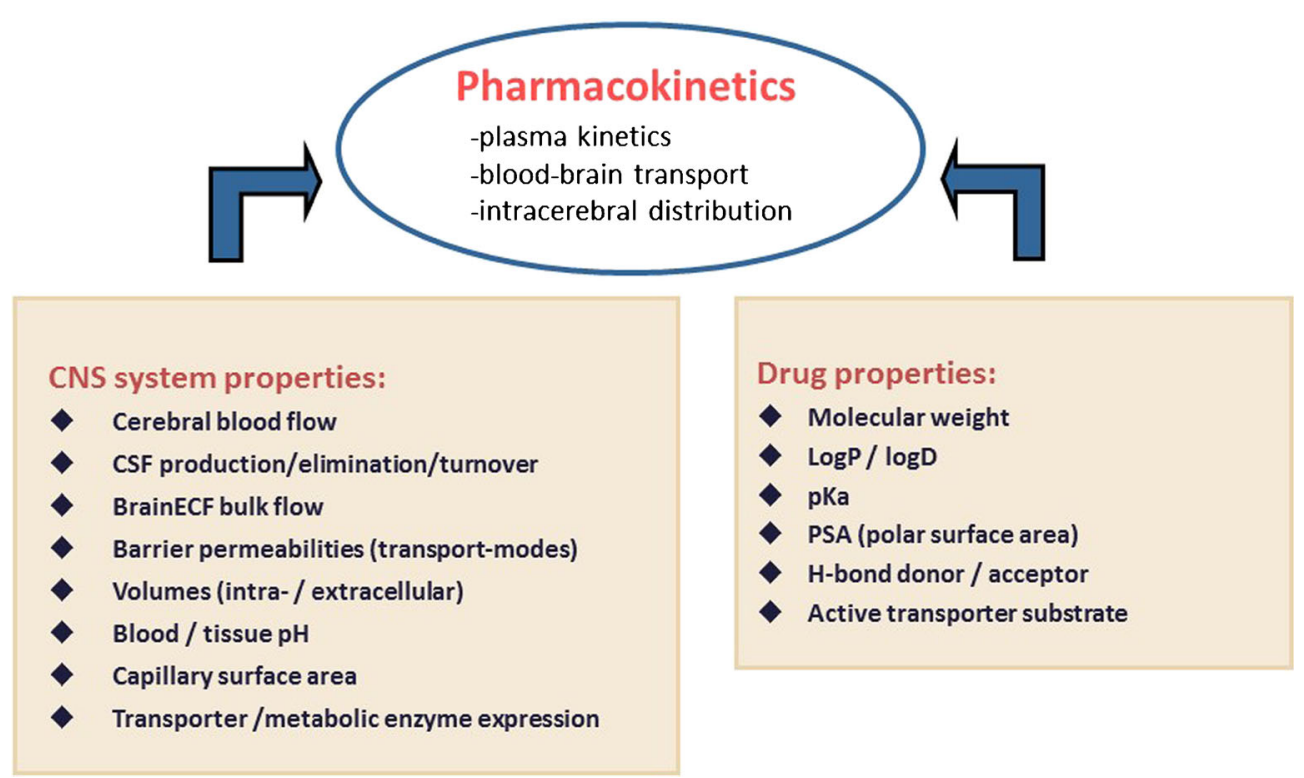

Fig. 1. System and drug properties which govern drug kinetics in brain. Figure is modified from de Lange (4) 


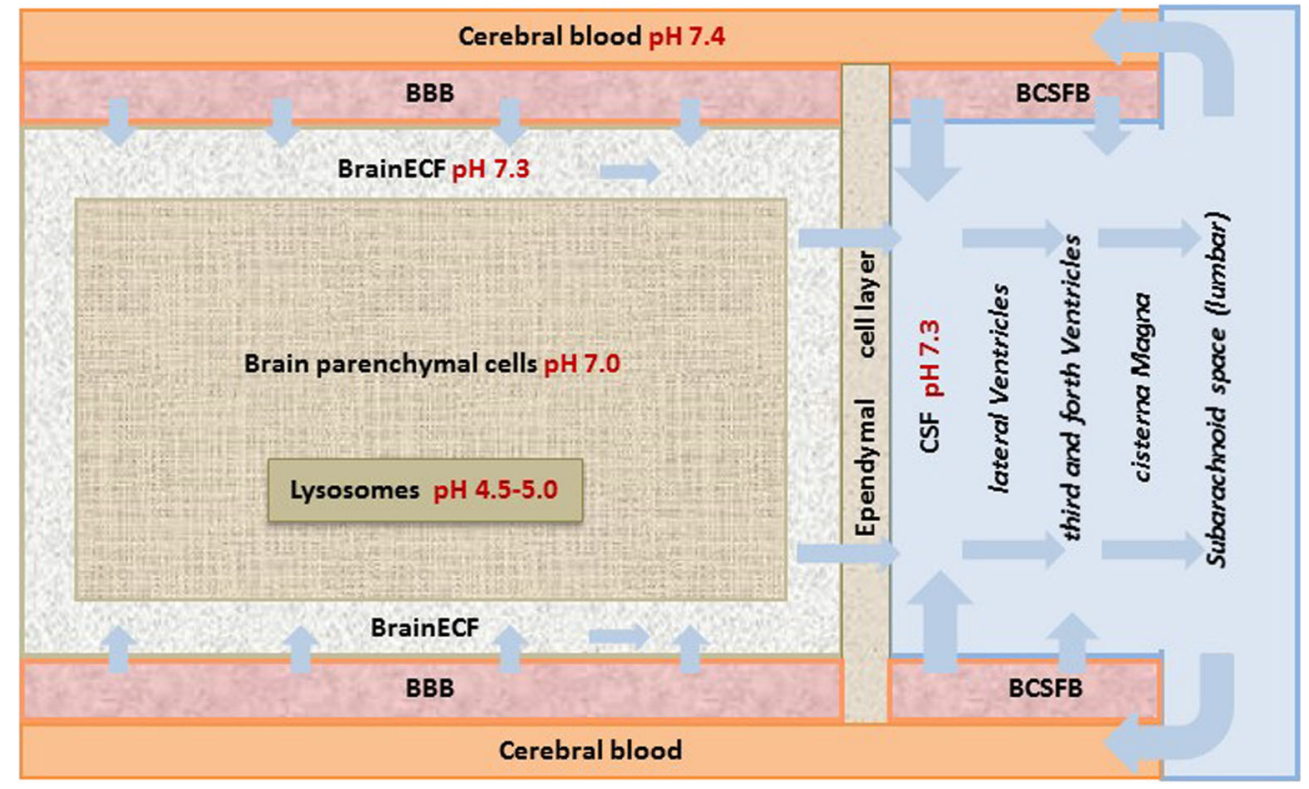

\section{Fluid}

flow

Fig. 2. Brain physiological components and flow. Figure is modified from de Lange (4)

transporters (OATs), is categorized as a facilitated transport, multidrug resistance protein (MRPs), and breast cancerwhile $\mathrm{ABC}$ transporters, such as P-glycoprotein (P-gp), resistant protein (BCRP) are categorized as an ATP-

Table I. Values of CNS system properties for rat and human

\begin{tabular}{|c|c|c|c|c|c|}
\hline & Parameter & Human & Refs & Rat & Refs \\
\hline \multirow[t]{10}{*}{ Volumes } & $\mathrm{BBB}$ volume & $\begin{array}{l}8.25 \mathrm{~mL} \text { (calculated using thickness } \\
\text { endothelial cell of } 550 \mathrm{~nm} \text { ) }\end{array}$ & $(17)$ & $5.02 \mu \mathrm{L}$ & (18) \\
\hline & BCSFB volume & $\begin{array}{l}107.25 \mathrm{~mL} \text { (calculated using } \\
\text { thickness } 14.3 \mu \mathrm{m} \text { of endothelial cell) }\end{array}$ & (19) & $37.5 \mu \mathrm{L}$ & $(18)$ \\
\hline & Brain volume & $1400 \mathrm{~g}$ & $(20)$ & $1.8 \mathrm{~g}, 1880 \mu \mathrm{L}$ & $(21,22)$ \\
\hline & Brain $_{\mathrm{ECF}}$ volume & $240-280 \mathrm{~mL}$ & $(23,24)$ & $290 \mu \mathrm{L}$ & $(25)$ \\
\hline & Brain $_{\text {ICF }}$ volume & $960 \mathrm{~mL}$ & (24) & $1440 \mu \mathrm{L}$ & (24) \\
\hline & CSF volume & $130-150 \mathrm{~mL}$ & $(26,27)$ & $250 \mu \mathrm{L}$ & (21) \\
\hline & $\mathrm{CSF}_{\mathrm{LV}}$ volume & $20-25 \mathrm{~mL}$ & $(26,28)$ & $50 \mu \mathrm{L}$ & $(29,30)$ \\
\hline & $\mathrm{CSF}_{\mathrm{TFV}}$ volume & $20-25 \mathrm{~mL}$ & $(26,28)$ & $50 \mu \mathrm{L}$ & $(29,30)$ \\
\hline & $\mathrm{CSF}_{\mathrm{CM}}$ volume & $7.5 \mathrm{~mL}$ & $(31,32)$ & $17 \mu \mathrm{L}$ & $(31,32)$ \\
\hline & $\mathrm{CSF}_{\mathrm{SAS}}$ volume & $90-125 \mathrm{~mL}$ & $(26,28)$ & $180 \mu \mathrm{L}$ & $(33,34)$ \\
\hline \multirow[t]{3}{*}{ Flows } & cerebral blood flow & $610-860 \mathrm{~mL} / \mathrm{min}$ & $(35-37)$ & $1.1-1.3 \mathrm{~mL} / \mathrm{min}$ & $(38,39)$ \\
\hline & brain $_{\mathrm{ECF}}$ flow & $0.15-0.2 \mathrm{~mL} / \mathrm{min},(50 \%$ of CSF production) & $(27)$ & $0.00018-0.00054 \mathrm{~mL} / \mathrm{min}$ & $(40)$ \\
\hline & CSF flow & $0.3-0.4 \mathrm{~mL} / \mathrm{min}$ & (27) & $0.0022 \mathrm{~mL} / \mathrm{min}$ & $(25,41)$ \\
\hline \multirow[t]{4}{*}{ Surfaces } & BBB SA & $12-18 \mathrm{~m}^{2}$ & (17) & $155-263 \mathrm{~cm}^{2}$ & $(42,43)$ \\
\hline & BCSFB SA & $\begin{array}{l}6-9 \mathrm{~m}^{2} \\
\text { (assumed } 50 \% \text { of BBB SA) }\end{array}$ & (17) & $\begin{array}{l}25-75 \mathrm{~cm}^{2} \\
\text { (assumed } 50 \% \text { of BBB SA) }\end{array}$ & $(42,44)$ \\
\hline & brain ECF/ICF SA & $228 \mathrm{~m}^{2}$ & Calculated a) & $3000 \mathrm{~cm}^{2}$ & (18) \\
\hline & brain ICF/lysosome SA & $12 \mathrm{~m}^{2}$ & Calculated ${ }^{\text {a) }}$ & $162 \mathrm{~cm}^{2}$ & Calculated a) \\
\hline \multirow[t]{5}{*}{$\mathrm{pH}$} & Plasma & 7.4 & $(13)$ & 7.4 & $(10)$ \\
\hline & Brain $_{\mathrm{ECF}}$ & NA & & 7.3 & (11) \\
\hline & Brain $_{\mathrm{ICF}}$ & 7.0 & (14) & 7.0 & (11) \\
\hline & lysosome & $4.5-5.0$ & (15) & 5.0 & (11) \\
\hline & $\mathrm{CSF}$ & 7.3 & (13) & 7.3 & (12) \\
\hline
\end{tabular}

brain $_{E C F}$, brain extracellular fluid compartment, brain $_{I C F}$ brain intracellular fluid compartment, $C S F_{L V}$ compartment of cerebrospinal fluid in lateral ventricle, $C S F_{T F V}$ compartment of cerebrospinal fluid in the third and fourth ventricle, $C S F_{C M}$ a compartment of cerebrospinal fluid in the cisterna magna, $C S F_{S A S}$ compartment of cerebrospinal fluid in the subarachnoid space, $S A$ surface area

${ }^{a}$ Calculation was performed based on an assumption that the brain cells and lysosome are spherical 
dependent transport (45). Table II summarizes an overview of transporters with their localization and their endogenous and exogenous substrates.

\section{Metabolic Enzymes}

Presence and localization of enzymes in the brain are also important factors to determine drug kinetics in the brain. In the brain, the following enzymes are found: oxidoreductases such as cytochrome P450 (CYPs) and monoamine oxidase (MAO), membrane-bound and soluble catechol-Omethyltransferase (COMT), and transferases such as uridine 5-diphospho (UDP) -glucuronosyltransferases (UGTs) and phenol sulfotransferase (PST) (68). In Table III, an overview is provided of the different enzymes with their localization and examples of their endogenous and exogenous substrates.

\section{SMALL-MOLECULE DRUG PROPERTIES AND INTERACTION WITH THE CNS SYSTEM}

A combination of CNS system properties and drug properties determines the pharmacokinetics of a drug in the CNS, including the CNS target site. Important physicochemical properties for determination of drug CNS pharmacokinetics are summarized in Fig. 1.

Physicochemical properties of a drug, such as lipophilicity, size, charge, hydrogen binding potential and polar surface area (PSA), are important determinants for pharmacokinetics of a drug. Many studies have investigated the influence of individual physicochemical properties on the BBB penetration in isolation. However, as physicochemical properties are highly inter-correlated, it is more appropriate to consider these properties in combination.

First of all, it should be noted that it is the unbound and neutral form of a drug molecules that is able to diffuse across barriers like the $\mathrm{BBB}$ and $\mathrm{BCSFB}$, depending on the concentration gradient of the unbound and neutral form of the drug on either side of a membrane. Lipophilicity relates to the BBB permeability, as transcellular diffusion rate $(93,94)$. Furthermore, as a rule of thumb, higher lipophilicity increases CNS tissue binding. Molecular size is an important factor for paracellular drug diffusion rate and also has an impact on transcellular diffusion rate at the $\operatorname{BBB}(93,95,96)$. The degree of ionization depends on the $\mathrm{pKa}$ of the drug and actual $\mathrm{pH}$ in a body compartment. Thus, the BBB permeability rate is influenced by lipophilicity, size, and $\mathrm{pKa}$ of a drug $(93,97)$. Using quantitative structure-activity relationship (QSAR) modeling, it has been shown that the descriptors for the prediction of $\mathrm{BBB}$ penetration are different for different charge classes (98). As there are $\mathrm{pH}$ differences between plasma, brain ${ }_{\mathrm{ECF}}$ and CSF (Fig. 2), charge is an important factor for CNS drug disposition (99).

The hydrogen bonding potential reflects the necessary energy for a molecule to move out of the aqueous phase into the lipid phase of a membrane. Recent studies have shown that the relationship between chemical structure and $\mathrm{Kp}$,uu,brain (the ratio of the unbound concentration in the brain over that in plasma at equilibrium which measures the extent of CNS distribution) was dominated by hydrogen bonding (100).
PSA is generally defined as the sum of the van der Waals surface areas of oxygen and nitrogen atoms. Therefore, PSA of a compound can be related to its hydrogen bonding potential. Some studies have shown that PSA is highly correlated with the permeability coefficient $(\mathrm{Pc})$ of membranes $(94,101,102)$. A recent study for Kp,uu,brain has been shown that PSA is one of the important factors to predict the Kp,uu,brain for each compound (103).

\section{BBB and BCSFB Transport}

Protein Binding. It is generally accepted that unbound drug in plasma is able to cross the BBB and BCSFB. Two major proteins in plasma are albumin and $\alpha 1$-acid glycoprotein (104). For passive diffusion, the free concentration gradient between plasma and brain determines the rate of transport. The extent of $\mathrm{BBB}$ and BCSFB transport are investigated using Kp,uu,brain: If there is only diffusion, Kp,uu,brain is 1 . If there is active transport processes, then Kp,uu,brain is larger than 1 (active in) or Kp,uu,brain is smaller than 1 (active out).

Ionization of the Drug in Plasma and in the Brain. There are similar $\mathrm{pH}$ differences among the CNS physiological compartments in human and in rat (Table I). Because of the $\mathrm{pH}$ differences, the ratio of neutral form of a compound among the compartments is different. It is generally accepted that neutral form can pass barriers; therefore, ionization that is determined by the $\mathrm{pKa}$ of a compounds and $\mathrm{pH}$ in the physiological compartments will have an impact on drug disposition in the brain.

Cerebral Blood Flow-Flow Versus Permeability-Limited Transport Rate. Lipophilic compounds usually have a large permeability coefficient; therefore, a permeability surface area product (PA), which is determined by the permeability coefficient and surface area of tissue, becomes large. If the PA is larger than the physiological cerebral blood flow, then the physiological cerebral blood flow determines the transport rate of the compound.

Modes of BBB Transport-Different Modes. The combination of transport modes at the BBB, BSCFB, and membrane of brain parenchyma determines the rate and extent of drug exchange at the BBB, BCSFB and membrane of brain parenchyma $(105,106)$. Therefore, the operative transport mechanism(s) may differ for each drug. Each transport mode is summarized in Table IV.

Active Transporter Function. Active transporters mediate influx and efflux of drug transport. The magnitude of interaction of active transport is drug- and species-dependent (107). The functions of individual transporters are summarized in Table II.

\section{Brain Distribution and Elimination}

Extra-intracellular Distribution. Once having crossed the $\mathrm{BBB}$, the drug is distributed by brain $\mathrm{ECF}_{\mathrm{E}}$ bulk flow into the 


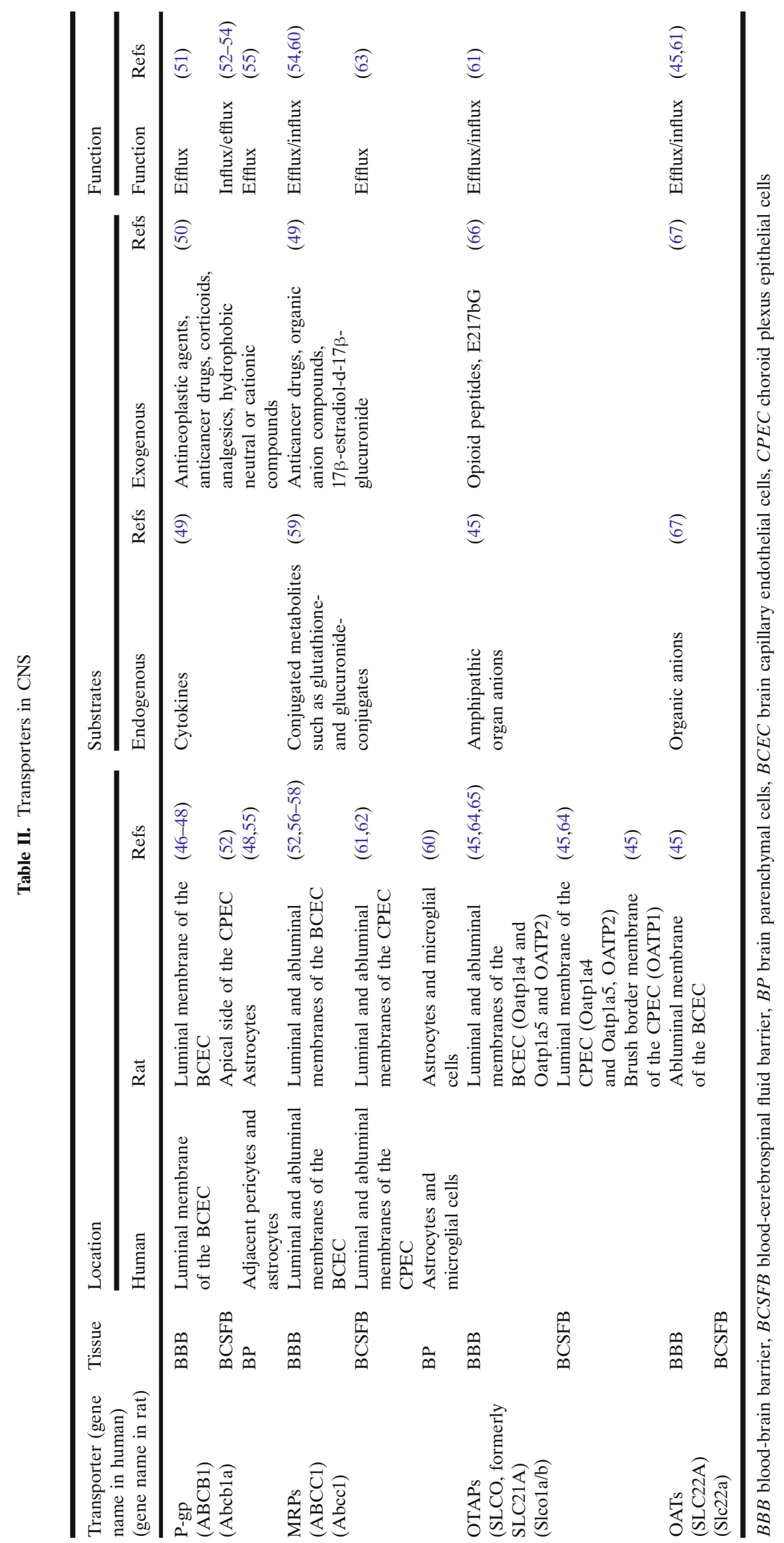




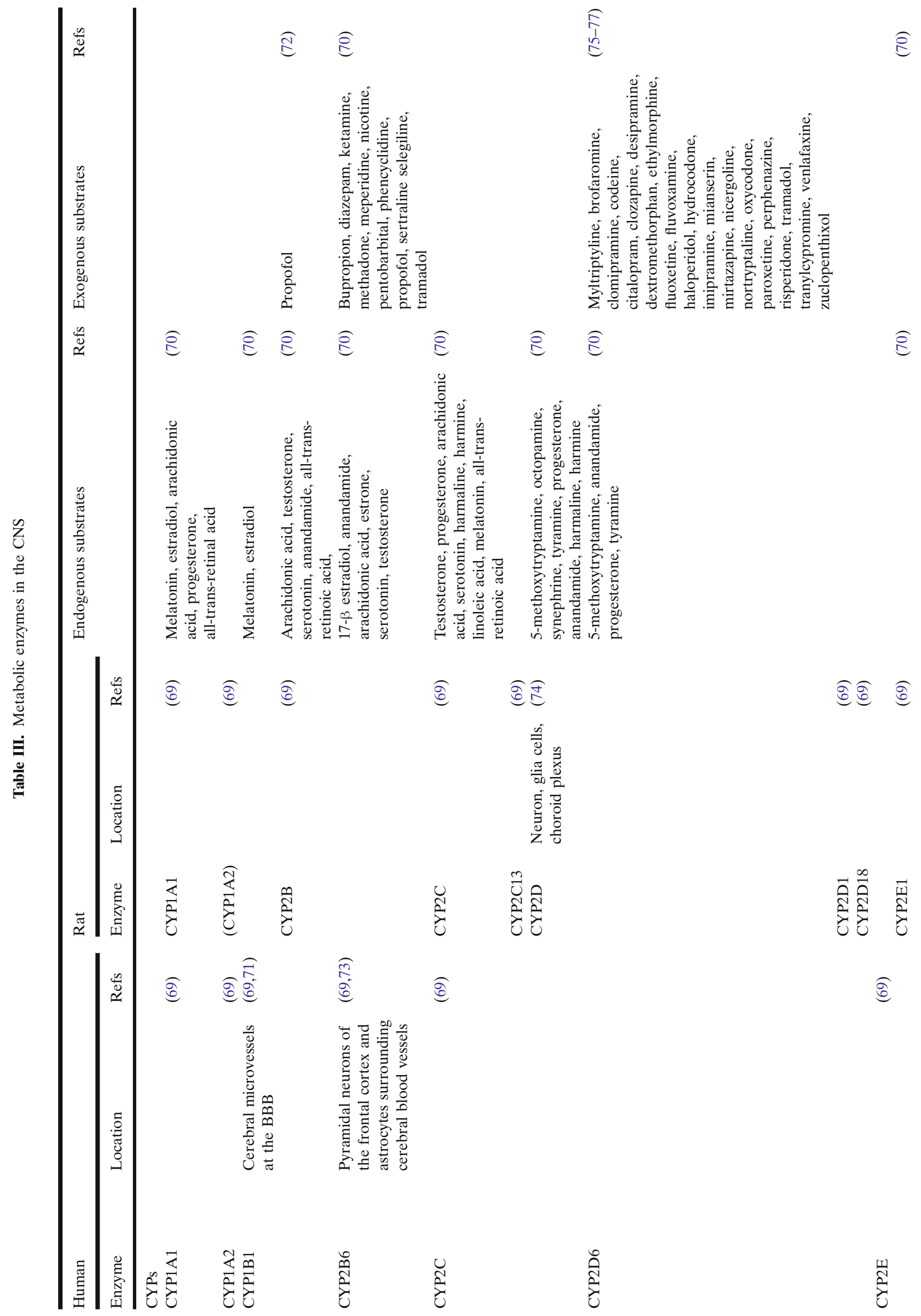




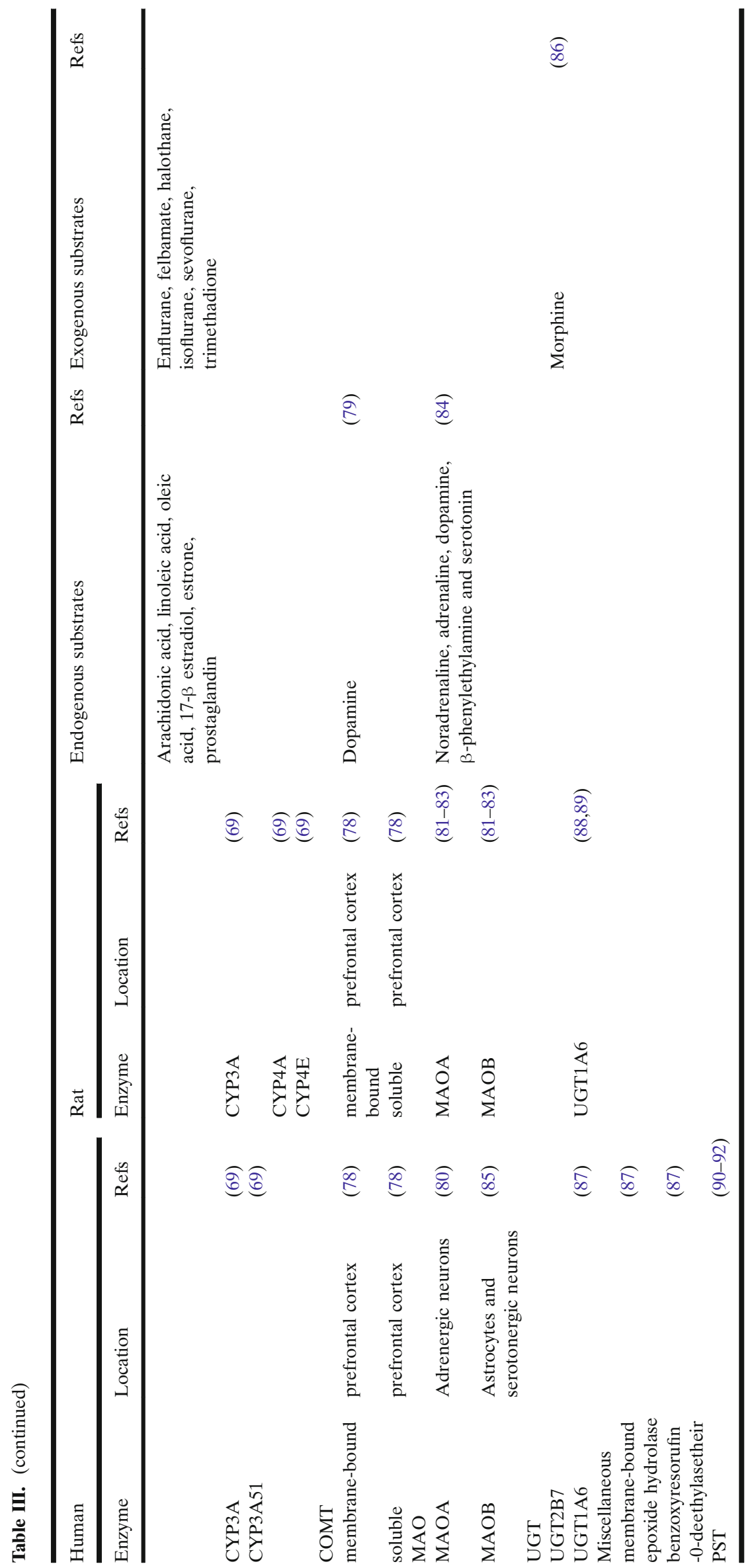


Table IV. Blood-brain barrier main modes of transport and their characteristics

\begin{tabular}{|c|c|c|c|c|}
\hline $\begin{array}{l}\text { BBB/BCSFB transport } \\
\text { mode }\end{array}$ & Characteristics & $\begin{array}{l}\text { Concentration- } \\
\text { dependent transport } \\
\text { kinetics? }\end{array}$ & $\begin{array}{l}\text { Drug } \\
\text { concentration- } \\
\text { gradient } \\
\text { dependent? }\end{array}$ & $\begin{array}{l}\text { Consumes } \\
\text { energy? }\end{array}$ \\
\hline Paracellular & $\begin{array}{l}\text { Passive; } \\
\text { Between tight junctions of the BCEC and the CPEC }\end{array}$ & No & Yes & No \\
\hline Transcellular & $\begin{array}{l}\text { Passive; } \\
\text { Across the membranes of the } \mathrm{BCEC} \text { and the CPEC }\end{array}$ & No & Yes & No \\
\hline Facilitated & Passive; & Yes & Yes & No \\
\hline Active influx & Active; & Yes & No & Yes \\
\hline Active efflux & Active; & Yes & No & Yes \\
\hline Transcytosis & $\begin{array}{l}\text { Receptor (specific, low capacity) or absorptive } \\
\text { mediated (non-specific, high capacity) }\end{array}$ & No & No & Yes \\
\hline
\end{tabular}

$B C E C$ brain capillary endothelial cells, $C P E C$ choroid plexus epithelial cells

CSF compartments. At the same time, the drug in brain ECF $_{\text {is }}$ transported to brain parenchymal cell intracellular fluid

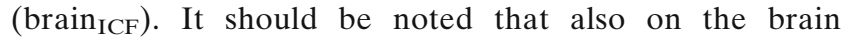
parenchyma cell membranes active transport may occur (106).

Tissue Binding. Tissue binding can occur as being specific at the target or non-specific to tissue components.

Lysosomal Trapping. In the brain parenchyma cells, there is a physiological $\mathrm{pH}$ gradient between the intracellular compartment (cytoplasm) and the lysosome compartment (Fig. 2). Especially basic compounds are known to be trapped in the lysosomes (11).

Drug Dispersion Within CSF. Some studies have shown that intrathecally administered drugs distribute faster than what can be accounted only by molecular diffusion (108, 109). Thus, it is thought that molecular diffusion makes only a small contribution to the total drug dispersion within CSF. This leads to the need to take into account also the convection due to oscillatory CSF flow to adequately explain this dispersion (110). Recently, the drug dispersion has been considered to be enhanced by the CSF pulsatility (heart rate and CSF stroke volume), and it leads to high inter- and intra-patient variability in drug distribution in the brain $(110,111)$.

Elimination from the Brain. Apart from transport across the $\mathrm{BBB}$ and $\mathrm{BCSFB}$ as discussed earlier, drug may leave the brain via the $\mathrm{BBB}$, but also via $\mathrm{CSF}$ reflux into the blood stream at the level of the arachnoid villi.

Metabolism. In the brain, several metabolic enzymes are present. Enzyme interaction with drugs is important information not only on the drug PK profile but also the drug pharmacological effect in the brain since it may create active metabolites. Presence and localization of several enzymes have been reported in the brain (Table III), although their activity is reported to be relatively small compared to the liver $(68,87)$.

\section{CURRENT APPROACHES TO INVESTIGATE CNS DRUG DISTRIBUTION}

Since obtaining a human drug target site concentration in the brain is not feasible in most of the clinical studies, quantitative prediction of target site concentration is important. To achieve this, we need information from in vitro, ex vivo, in vivo, and in silico approaches. Here, we summarize the current approaches to obtain the necessary information to predict human drug target site concentration.

\section{IN SILICO APPROACHES}

For decades, QSAR studies have been performed using $\mathrm{Kp}$,brain (total concentration ratio of the brain to plasma) or log $\mathrm{BB}$, either of which may not reflect the relevant drug exposure in the brain to assess the efficacy of the drug since this efficacy is influenced by binding of compounds to plasma proteins and brain tissue. Eventually, $\log$ BB was replaced by the PA, as an estimate of the net BBB influx clearance (112). However, it has been argued that the PA cannot predict the unbound drug concentration in the CNS by itself. Recently, the most relevant parameter Kp,uu,brain has been used, with QSAR being conducted to model this parameter $(100,103,113,114)$. Other than Kp,uu,brain, physiological meaningful parameter, Vu,brain (the volume of distribution of the unbound drug in the brain) or Kp,uu,cell (unbound concentration ration between brain $_{\mathrm{ECF}}$ and brain $_{\mathrm{ICF}}$ ) are also reported using molecular descriptors (103).

\section{IN VITRO APPROACHES}

In vitro approaches to investigate the $\mathrm{BBB}$ permeability have been conducted using BBB models (115). BBB models can be classified into non-cell based surrogate models, such as parallel artificial membrane permeability assay (PAMPA), and cell-based models such as primary cultures cells, immortalized brain endothelial cells, or human-derived stem cells (116). Although primary cultured cells from human tissue have been reported, acquiring human brain tissue is difficult as it can be 


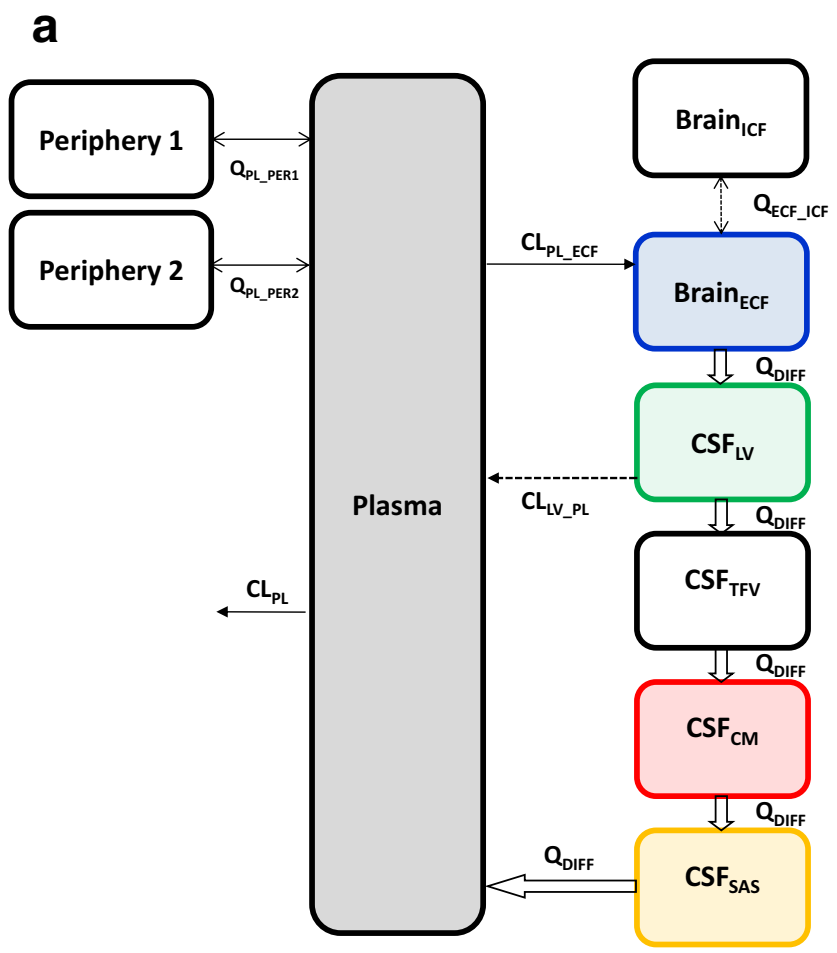

b
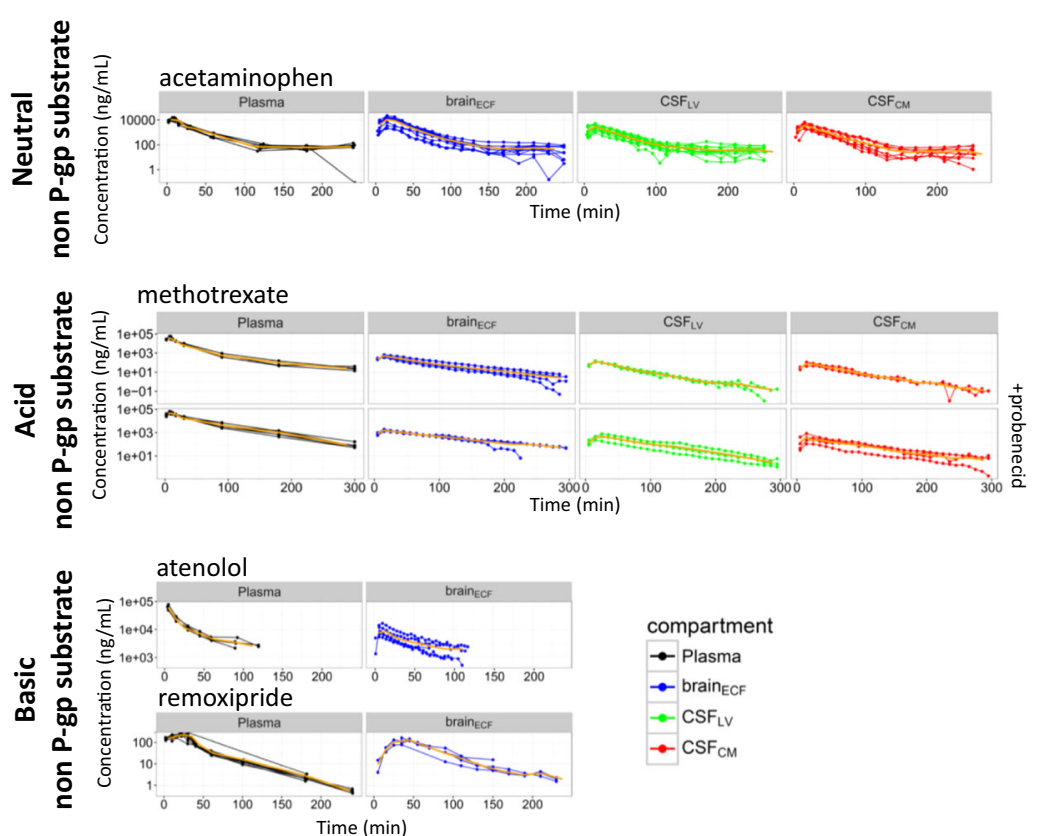

Fig. 3. A generic multi-compartmental CNS distribution model. (a) Multicompartmental CNS distribution model structure. (b) and (c) Observations and model prediction (light orange solid lines) for the 9 compounds in rat for each dose and without and with co-administration of active transport blockers. The $\mathrm{x}$-axis represents the time in minutes and the y-axis represents the concentration of the 9 compounds in $\mathrm{ng} / \mathrm{ml}$. The panel is stratified by brain compartments (colors) and by active transport blockers

obtained postmortem and should be fresh enough (117). Therefore, alternative models based on immortalized brain endothelial cells or human-derived stem cells are also used $(118,119)$. Even though some models have been developed for measuring the BBB permeability, an ideal cell culture model of the BBB is yet to be developed. Furthermore, reliable in vitro-in vivo correlation data is needed to enable the use of in vitro results for the prediction of in vivo permeability. However, in vitro results have not been consistent in their ability to predict in vivo permeability, probably because of 

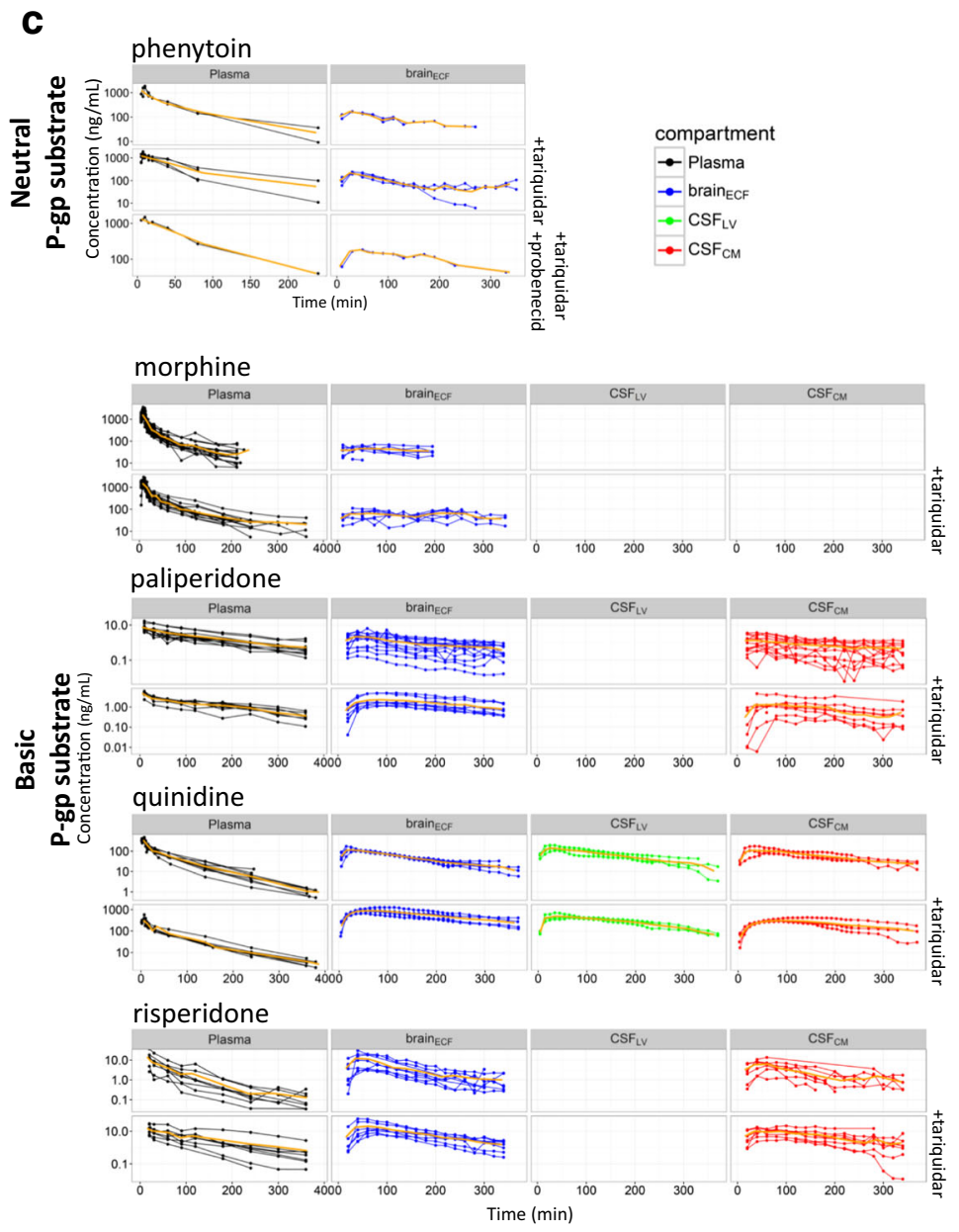

Fig. 3. (Continued)

different in vitro models and different sets of compounds used in the in vitro studies (120).

Currently, the biopharmaceutics classification system (BCS) and biopharmaceutics drug distribution classification system (BDDCS) are used for CNS drugs. The BDDCS is a modification of BCS that utilizes drug metabolism to predict drug disposition and potential drug-drug interactions in the brain (121). However, this classification approach needs to be further investigated because of inconsistencies. For example, it was proposed that $98 \%$ of BDDCS class 1 drugs would be able to get into the brain even though the drugs were P-gp substrates based on in vitro studies (122), while it has also been reported that the in vitro efflux ratio reflects the in vivo brain penetration regardless of the class in BDDCS (123).

\section{EX VIVO APPROACHES}

As mentioned before, it is the unbound drug molecules that are able to pass membranes and to interact with the target (21). Thus, measuring unbound drug concentrations is very important. Vu,brain or Fu,brain (the unbound fraction in the brain) is used to investigate unbound fraction of drugs in the brain. Fu,brain can be derived from brain homogenate (124), and Vu,brain can be obtained from the brain slice technique (125). The brain slice method is more physiologically relevant because the cell-cell interactions, $\mathrm{pH}$ gradients, and active transport systems are all conserved (114).

\section{IN VIVO APPROACHES}

Microdialysis can be considered as a key technique to timedependent information regarding unbound drug concentrations. With microdialysis, both the rate and extent of drug transport and distribution processes can be determined $(126,127)$. Thus, it can be used to obtain Kp,uu,brain in conjunction with the rate of transport processes. Moreover, this can be done at multiple locations, and this feature has shown that even for a drug like acetaminophen that is not subjected to any active transport, substantial differences in pharmacokinetic profiles exist in different brain compartments (6). While there is some limit to use this water-based technique for the highly lipophilic drugs, lots of microdialysis experiments have contributed to a boost in the understanding on drug exchange across the BBB $(126,128,129)$. Especially the use of microdialysis at multiple brain locations has provided insight into the relative contribution of CNS distribution and elimination processes to the local (differences in) pharmacokinetics of a compound $(6,7,130)$. It has paved the way to the development of a generic multi-compartmental CNS distribution 
Table V. Sources of variability in CNS pharmacokinetics

\begin{tabular}{|c|c|c|c|c|}
\hline Parameter & Location & Source of variability & Effect & Refs \\
\hline \multirow[t]{2}{*}{ Protein binding } & & Aging & Lower & $(139)$ \\
\hline & & $\begin{array}{l}\text { Pathophysiological } \\
\text { condition }\end{array}$ & Higher with disease induced evaluation of plasma protein & $(140,141)$ \\
\hline \multirow[t]{3}{*}{ Cerebral blood flow } & & Aging & Lower & $(142)$ \\
\hline & & $\begin{array}{l}\text { Pathophysiological } \\
\text { condition }\end{array}$ & Lower in the multi-infarct group & $(143)$ \\
\hline & & Diurnal variation & Change & $(144)$ \\
\hline \multirow[t]{12}{*}{ BBB } & Membrane lipid & Aging & Change & $(145)$ \\
\hline & & Diet & Change & $(146)$ \\
\hline & & $\begin{array}{l}\text { Pathophysiological } \\
\text { condition }\end{array}$ & $\begin{array}{l}\text { Change in several disease conditions, such as } \\
\text { Alzheimer's disease (AD) and schizophrenia }\end{array}$ & $(147-149)$ \\
\hline & Paracellular diffusion & Stress & Increase with hypoxic stress & $(150)$ \\
\hline & & $\begin{array}{l}\text { Pathophysiological } \\
\text { condition }\end{array}$ & Increase (due to loose of tight junctions) & see below \\
\hline & Tight junction & Pathophysiological & Disruption of the tight junctions by ischaemic brain stroke & $(151)$ \\
\hline & & condition & Opening of the tight junctions in $\mathrm{AD}$ patients & $(152)$ \\
\hline & & & Opening of tight junctions in multiple sclerosis patients & $(153)$ \\
\hline & Facilitated transport & Diet & Decreased in hypoglycemia condition & $(154)$ \\
\hline & & $\begin{array}{l}\text { Pathophysiological } \\
\text { condition }\end{array}$ & Upregulation in the brain tumor & $(155)$ \\
\hline & $\begin{array}{l}\text { Vesicle-based } \\
\text { transport }\end{array}$ & $\begin{array}{l}\text { Pathophysiological } \\
\text { condition }\end{array}$ & Increase in experimental autoimmune encephalomyelitis & $(156)$ \\
\hline & Active transporters & $\begin{array}{l}\text { Pathophysiological } \\
\text { condition }\end{array}$ & See below & see below \\
\hline \multirow[t]{2}{*}{ Brain $_{\mathrm{ECF}}$} & & $\begin{array}{l}\text { Pathophysiological } \\
\text { condition }\end{array}$ & $\begin{array}{l}\text { Volume is enlarged in the patient with vasogenic type } \\
\text { of brain }\end{array}$ & $(157)$ \\
\hline & & & Blockade of brain ECF flow in $\mathrm{AD}$ patient & $(41)$ \\
\hline Brain parenchyma & & Aging & Shrunk & $(158)$ \\
\hline \multirow[t]{2}{*}{ BCSFB } & & Aging & Thinner & $(159)$ \\
\hline & & $\begin{array}{l}\text { Pathophysiological } \\
\text { condition }\end{array}$ & Decrease in Alzheimer patients & $(159)$ \\
\hline \multirow[t]{3}{*}{ CSF } & & Aging & $\begin{array}{l}\text { Decrease in CSF production, increase in CSF outflow } \\
\text { resistance }\end{array}$ & $(160)$ \\
\hline & & $\begin{array}{l}\text { Pathophysiological } \\
\text { condition }\end{array}$ & $\begin{array}{l}\text { Decrease in CSF production, CSF Turnover and increase } \\
\text { in CSF volume in AD patients }\end{array}$ & $(161)$ \\
\hline & & & $\begin{array}{l}\text { Increased resistance to CSF absorption and CSF pressure } \\
\text { in the patients with } \\
\text { normal-pressure hydrocephalus }\end{array}$ & $(162)$ \\
\hline \multirow{7}{*}{$\begin{array}{l}\text { Brain metabolic } \\
\text { enzymes }\end{array}$} & & Aging & Increase in the CYP2D6 enzyme level & $(163)$ \\
\hline & & Gender & Higher MAO activity in women & $(83)$ \\
\hline & & $\begin{array}{l}\text { Pathophysiological } \\
\text { condition }\end{array}$ & Higher MAOB activity in $\mathrm{AD}$ patients & $(164)$ \\
\hline & & & Difference of COMT expression in schizophrenia patients & $(78)$ \\
\hline & & Gene & Deficiency of CYP2D6 enzyme & $(75)$ \\
\hline & & & Change of COMT function & $(165,166)$ \\
\hline & & Smoking and alcoholism & Change of CYP2B6 and CYP2E1 levels & $(73,167)$ \\
\hline \multirow[t]{6}{*}{ Transporter } & & Aging & Decrease in P-gp activity & $(168)$ \\
\hline & & & Decrease in glucose transporter activity & (169) \\
\hline & & $\begin{array}{l}\text { Pathophysiological } \\
\text { condition }\end{array}$ & Upregulation of P-gp and MRPs in epileptogenic brain & $(170)$ \\
\hline & & & Upregulation of P-gp and MRP1 in the brain tumor & $(171)$ \\
\hline & & & $\begin{array}{l}\text { Alteration of the levels of glutamate transporter in the } \\
\text { various brain disorders, including cerebral ischemia, } \\
\text { amyotrophic lateral sclerosis, AD, AIDs, } \\
\text { traumatic brain injury, schizophrenia, and epilepsy } \\
\text { (seizure) }\end{array}$ & $(172,173)$ \\
\hline & & Diurnal variation & Change in P-gp activity & (174) \\
\hline
\end{tabular}


Table VI. Currently published (semi-) PBPK model for CNS drugs

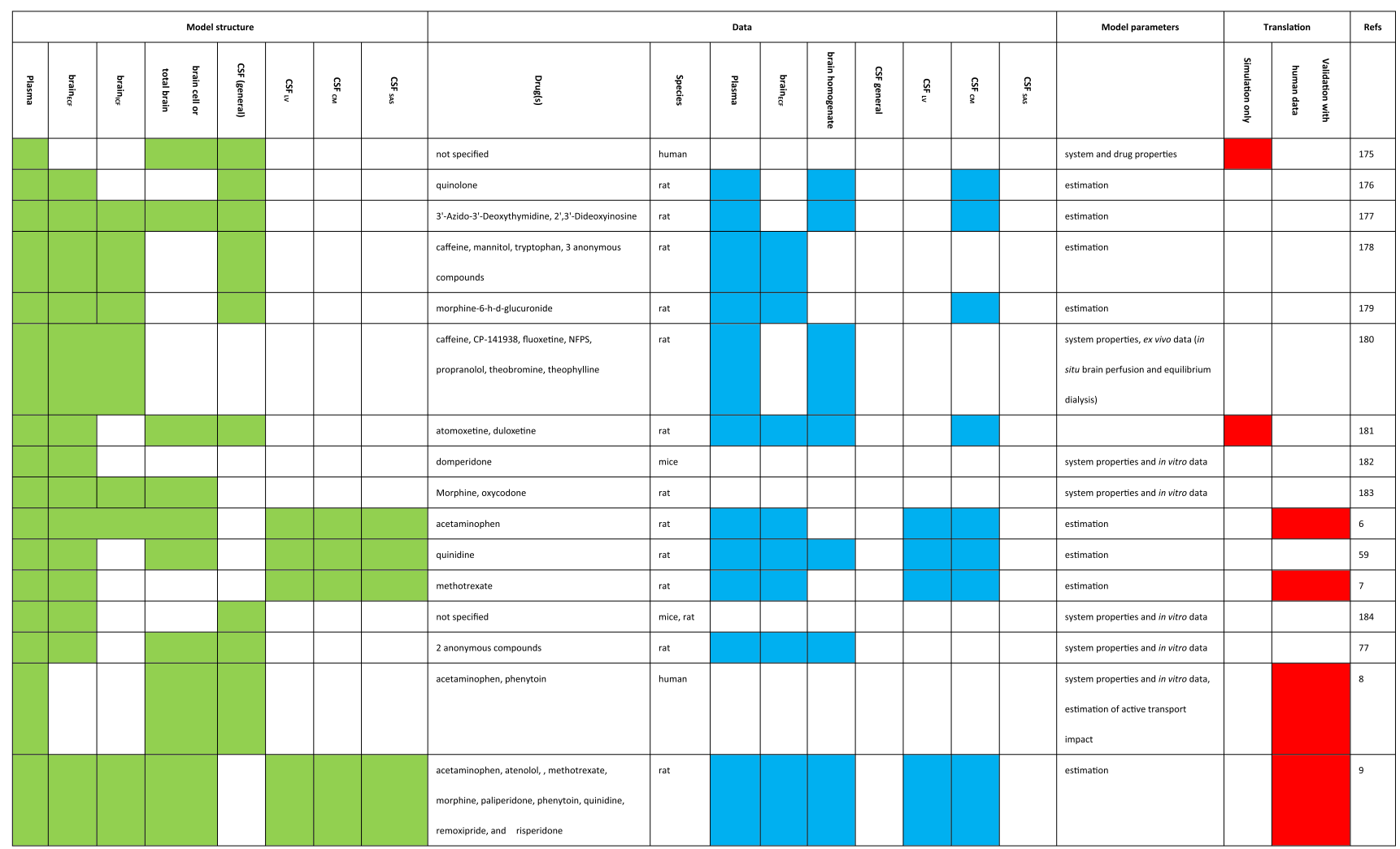

The green boxes represent which physiological compartments were taken into account in each model structure. The blue boxes show which compartment data was used for each modeling if in vivo data was used. The red boxes explain what translational research was performed with each model if applicable

model (Fig. 3), with some validated human CNS predictions that will be discussed later in this review.

Then, positron emission tomography (PET) is a valuable non-invasive in vivo monitoring technique that can be used to visualize drug CNS distribution in living animals and human. However, the PET technique cannot distinguish parent compounds from their metabolites or bound and unbound drug. Furthermore, it may also encounter difficulties in obtaining useful data when a very high non-specific binding (NSB) to nontarget proteins and phospholipid membranes occurs (131). Recently, a novel lipid membrane binding assay (LIMBA) was established as a fast and reliable tool for identifying compounds with unfavorably high NSB in the brain tissue (132).

\section{COMBINATORY MAPPING APPROACH}

Combinatory mapping is an approach that combines three compound-specific parameters obtained from in vitro, ex vivo, and in vivo data: Kp,brain, Vu,brain, and Fu,plasma, for calculation of Kp,uu,brain (133). This approach also can be used to obtain not only Kp,uu,brain but also to understand unbound drug disposition in the cell cytosol and the lysosomes. Recently, this approach has been extended to predict drug exposure in different brain regions such as frontal cortex, striatum, hippocampus, brainstem, cerebellum, and hypothalamus, in which also the impact of transporters and receptors in each region was taken into account (134). Although this approach is useful to support the selection of potential CNS drugs in drug discovery, it has two limitations. The first limitation is that it can only predict the parameters at steady-state. The second limitation is that the approach cannot be translated to predict the parameters, for instance, inter-species or interdisease conditions because the processes to obtain the parameters in this approach are not connected with system properties which will be changed in these conditions.

\section{CONDITION DEPENDENCY AND PBPK MODELING}

\section{Condition Dependency}

Drug distribution into and within the brain depends on the interaction between system and drug properties. Drug properties remain the same, whatever the species and conditions are in which the drug has been administered. This indicates that interspecies variability in drug distribution into and within the brain is the result of differences in physiological and biochemical parameters. Factors which cause variation in drug pharmacokinetics include genetic background, species differences, gender, age, diet, disease states, and drug treatment (4). Factors which cause variation in drug pharmacodynamics include seasonal 


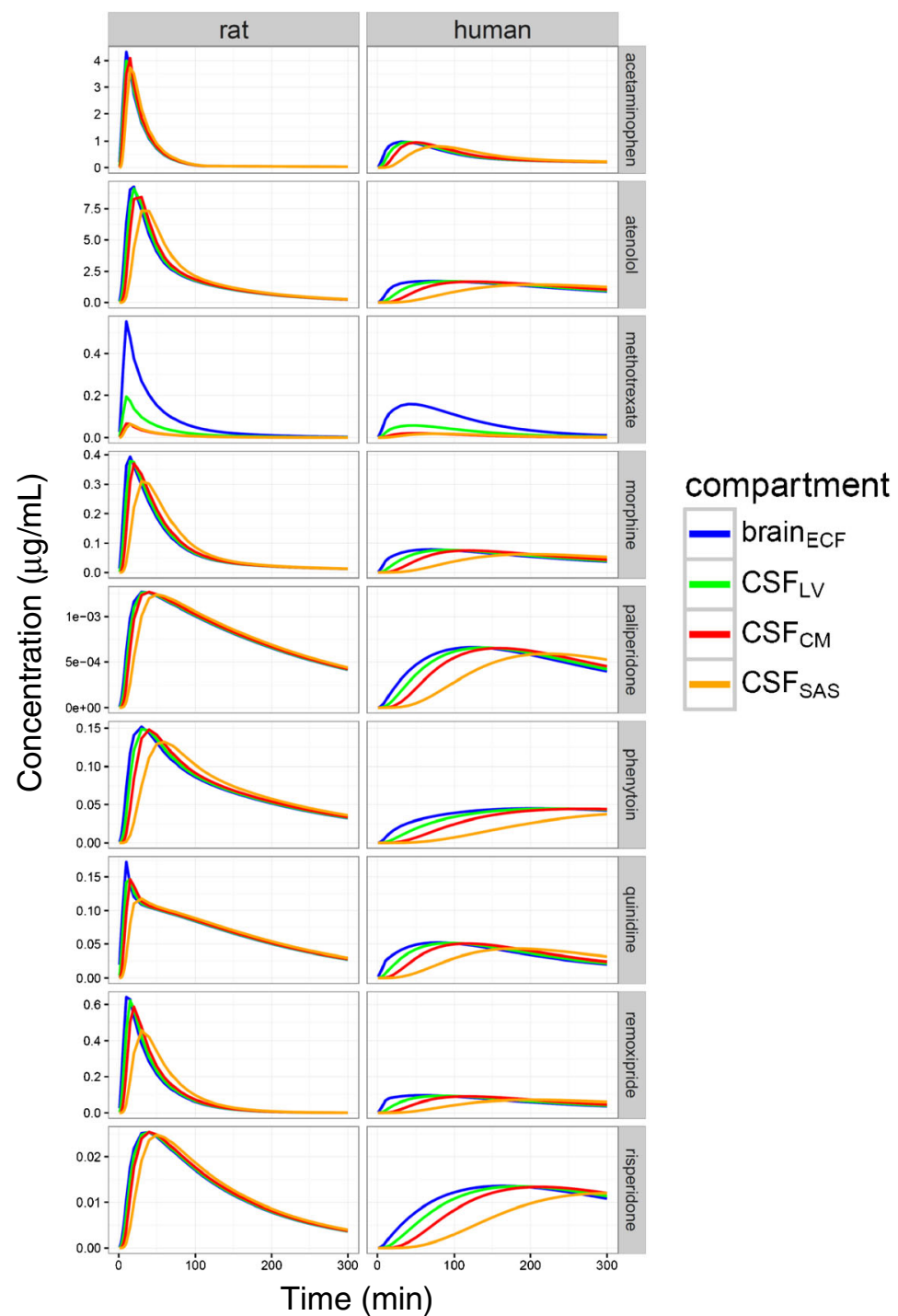

Fig. 4. Simulation of time concentration profiles of brain $_{\mathrm{ECF}}, \mathrm{CSF}_{\mathrm{LV}}, \mathrm{CSF}_{\mathrm{CM}}$ and $\mathrm{CSF}_{\mathrm{SAS}}$ in rat and human for the 9 compounds. Differences in the time concentration between rat and human reflected the differences of the rate and extent of drug distribution in brain between in rat and in human since identical plasma exposure was used as an input

effect (135), age (136), gender (137), and species (138). Influences of these conditions on CNS system properties are summarized in Table V.

\section{(Semi-) PBPK Modeling}

PBPK models need to be informed on system and on drug properties to model the interaction and predict the PK in different compartments. Especially as obtaining pharmacokinetic data from the human brain is highly restricted, working in the PBPK model framework is valuable as it can be translated to predict the target site concentrations in inter-species and inter-disease situations (4). Some translational studied have been reported by using an animal (semi-) PBPK model for CNS drugs but they are relatively sparse and range from simple to more advanced (Table VI).
Recently, a generic multi-compartmental CNS distribution model structure has been proposed, that could successfully describe the pharmacokinetics in plasma and different

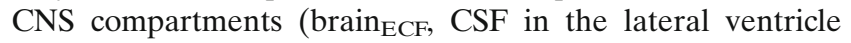
$\left(\mathrm{CSF}_{\mathrm{LV}}\right)$ and $\mathrm{CSF}$ in the cisterna magna $\left.\left(\mathrm{CSF}_{\mathrm{CM}}\right)\right)$, using microdialysis data for 9 paradigm compounds with substantial differences in physicochemical properties (9) (Table VI, Fig. 3). These compounds are acetaminophen, atenolol, methotrexate, morphine, paliperidone, phenytoin, quinidine, remoxipride, and risperidone. This is the first model that can nicely predict human brain ${ }_{\mathrm{ECF}}$ and CSF time concentration profiles which were obtained from physiologically "close to normal" brain for morphine and acetaminophen (9).

For remoxipride, Stevens et al. have shown that brain ${ }_{\mathrm{ECF}}$ pharmacokinetics, as measured with microdialysis, represented the target site concentrations, because these concentrations could be directly linked to the effect of remoxipride 
on plasma prolactin levels in an advanced mechanism-based model (185). After scaling to human, this indeed could also be concluded for human CNS remoxipride effects on human plasma prolactin levels. This underscores the importance of having information on pharmacokinetics at the CNS target region.

Using our generic multi-compartmental CNS distribution model, we can provide predictions of human CNS pharmacokinetics for all the nine compounds. For a direct comparison of rat and human pharmacokinetics in the different CNS compartments in response to plasma pharmacokinetics, the same plasma exposure was used for individual compound. In Fig. 4, it can be seen that, in general, human CNS pharmacokinetics, especially that in the CSF in the subarachnoid space $\left(\mathrm{CSF}_{\mathrm{SAS}}\right)$, which is including the lumbar CSF is typically slower than that in the rat. This provides important information on the relationship between brain $_{\mathrm{ECF}}$ (which often is the target site) pharmacokinetics and the lumbar CSF concentrations that are often used as biomarker of brain target site concentrations. Also, it can be seen that the differences in the pharmacokinetics at the more early time points of the different CNS compartments is larger in human than in the rat. With time, these differences fade out. The consequences for drug-target interaction kinetics (186) and further processes towards CNS drug effects remain to be determined.

\section{Remaining Gaps and Challenges on PBPK Modeling, Towards a Generic PBPK Model}

The ultimate aim is to have a CNS PBPK model that can predict human brain compartment concentrations on the basis of the physicochemical properties of a compound, which can be determined by in vitro measurements, or in silico prediction. Thus, in the overview in Table VI, it can be seen that we still have a number of gaps in the currently available (semi-) PBPK models of CNS drugs. Most of the models require in vivo data on the compound(s), and most of the predictions have not been validated on human data. Even the most comprehensive model (9), with validated prediction of human CNS drug distribution (for acetaminophen and morphine), still requires in vivo data for individual compound predictions. Thus, it can be seen that there is a need for further development of a generic, fully PBPK model for CNS drug distribution (187-189).

To have a PBPK model that would predict CNS drug distribution, based the physicochemical properties of an individual drug, for different species and in different conditions, a number of challenges remain:

- Having a PBPK model structure with all relevant compartment/parameters, as physiological parameter values reported are sparse and variable (see Table I).

- Having drug physicochemical parameter values from in vitro, and/or in silico, or even some in vivo measurements, which may not necessarily be correct. For example, in vitro or in vivo data may depend on the experimental setting, while in silico information really depends on the data availability, used to obtain the equation.

- Having human data sets for validation of prediction by the model, with typically limited availability.

- Having information on pathophysiological changes in human CNS properties in (the many) disease conditions. For example, BBB characteristics may change in Alzheimer's disease, multiple sclerosis, and pharmacoresistant epilepsies (190).

\section{DISCUSSION AND CONCLUSION}

Pharmacokinetics of drugs in the CNS is governed by a combination of CNS system physiology and drug properties. This means that variability in CNS system physiological parameters (condition dependency) may lead to variability of CNS pharmacokinetics. Therefore, it is important to explicitly distinguish between system physiology and drug properties, either by changing conditions and investigating the pharmacokinetics of one drug, or investigating the pharmacokinetics of different drugs in the same condition.

PBPK models make this distinction; however, being based on total drug plasma and total tissue concentrations at equilibrium (SS), while more recent PBPK models include, at best, unbound plasma SS concentrations. However, as body processes are based on the interaction with the unbound drug and are time-dependent, it is crucial to include measuring the unbound drug in each compartment as a function of time (Mastermind Research Approach (MRA)) (4), for which microdialysis has been proven the key technique. Using the MRA, microdialysis has provided lots of valuable data that pave the way towards a semiphysiological generic CNS drug distribution model, yet applicable for nine compounds with highly different physicochemical properties with excellent description of the rat data for all these compounds, and adequate prediction of human CNS data that were available for acetaminophen and morphine (9).

One microdialysis experiment in a single freely moving animal can provide a lot of data points, obtained under the same experimental condition of the animal, and thereby revealing the interrelationships of processes. With this microdialysis has already contributed to reduction and refinement in the use of animals. Furthermore, all this information can further be "condensed" into a generic PBPK model and will thereby help in the reduction in the future use of animals (replacement) (191).

So, in order to be able to predict CNS drug effects in human, next steps would be a development of a full PBPK CNS drug distribution model, and combine it with target binding kinetics, receptor occupancy, and signal transduction $(186,192)$, and include system changes by human disease condition.

\section{ACKNOWLEDGEMENTS}

This research article was prepared within the framework of project no. D2-501 of the former Dutch Top Institute Pharma, currently Lygature (Leiden, the Netherlands; www.lygature.org). 


\section{COMPLIANCE WITH ETHICAL STANDARDS}

Conflict of Interest The authors declare that they have no conflict of interest.

Open Access This article is distributed under the terms of the Creative Commons Attribution 4.0 International License (http://creativecommons.org/licenses/by/4.0/), which permits unrestricted use, distribution, and reproduction in any medium, provided you give appropriate credit to the original author(s) and the source, provide a link to the Creative Commons license, and indicate if changes were made.

\section{REFERENCES}

1. Kola I, Landis J. Can the pharmaceutical industry reduce attrition rates? Nat Rev Drug Discov. 2004;3:1-5.

2. Hurko O, Ryan JL. Translational research in central nervous system drug discovery. J Am Soc Exp Neurother. 2005;2(4):67182.

3. Cook D, Brown D, Alexander R, March R, Morgan P, Satterthwaite $\mathrm{G}$, et al. Lessons learned from the fate of AstraZeneca's drug pipeline: a five-dimensional framework. Nat Rev Drug Discov. 2014;13(6):419-31.

4. De Lange ECM. The mastermind approach to CNS drug therapy: translational prediction of human brain distribution, target site kinetics, and therapeutic effects. Fluids Barriers CNS. 2013;10(1):1-16.

5. Palmer AM, Stephenson FA. CNS drug discovery: challenges and solutions. Drug News Perspect. 2005;18(1):51-7.

6. Westerhout J, Ploeger B, Smeets J, Danhof M, de Lange ECM. Physiologically based pharmacokinetic modeling to investigate regional brain distribution kinetics in rats. AAPS J. 2012;14(3):543-53.

7. Westerhout J, Van Den Berg D-J, Hartman R, Danhof M, De Lange ECM. Prediction of methotrexate CNS distribution in different species-influence of disease conditions. Eur J Pharm Sci. 2014;57:11-24.

8. Gaohua L, Neuhoff S, Johnson TN, Rostami-hodjegan A, Jamei M. Development of a permeability-limited model of the human brain and cerebrospinal fluid (CSF) to integrate known physiological and biological knowledge: estimating time varying CSF drug concentrations and their variability using in vitro data. Drug Metab Pharmacokinet. 2016;31(3):224-33.

9. Yamamoto Y, Välitalo PA, van den Berg D-J, Hartman R, van den Brink W, Wong YC, et al. A generic multi-compartmental CNS distribution model structure for 9 drugs allows prediction of human brain target site concentrations. Pharm Res. 2017;34(2):333-51.

10. Mutch W. a, Hansen a J. Extracellular $\mathrm{pH}$ changes during spreading depression and cerebral ischemia: mechanisms of brain pH regulation. J Cereb Blood Flow Metab. 1984;4(1):17-27.

11. Fridén $\mathrm{M}$, Bergström $\mathrm{F}$, Wan $\mathrm{H}$, Rehngren $\mathrm{M}$, Ahlin $\mathrm{G}$, Hammarlund-Udenaes $\mathrm{M}$, et al. Measurement of unbound drug exposure in brain: modeling of $\mathrm{pH}$ partitioning explains diverging results between the brain slice and brain homogenate methods. Drug Metab Dispos. 2011;39(3):353-62.

12. Shu C, Shen H, Teuscher NS, Lorenzi PJ, Keep RF, Smith DE. Role of PEPT2 in peptide/mimetic trafficking at the bloodcerebrospinal fluid barrier: studies in rat choroid plexus epithelial cells in primary culture. J Pharmacol Exp Ther. 2002;301(3):820-9.

13. Shen DD, Artru AA, Adkison KK. Principles and applicability of CSF sampling for the assessment of CNS drug delivery and pharmacodynamics. Adv Drug Deliv Rev. 2004;56(12):1825-57.
14. Jwnsen KE, Thomsen C, Henriksen O. In vivo measurement of intracellular $\mathrm{pH}$ in human brain during different tensions of carbon dioxide in arterial blood. A31P-NMR study. Acta Physiol Scand. 1988;134(2):295-8.

15. Mindell JA. Lysosomal acidification mechanisms. Annu Rev Physiol. 2012;74:69-86.

16. Touitou E, Barry BW. Enhancement in Drug Delivery. 2006. 575-591 p.

17. Wong $\mathrm{AD}, \mathrm{Ye} \mathrm{M}$, Levy $\mathrm{AF}$, Rothstein JD, Bergles DE, Searson PC. The blood-brain barrier: an engineering perspective. Front Neuroeng. 2013;6:1-22.

18. Trapa PE, Belova E, Liras JL, Scott DO, Steyn SJ. Insights from an integrated physiologically based pharmacokinetic model for brain penetration. J Pharm Sci. 2016;105(2):965-71.

19. Serot JM, Béné MC, Foliguet B, Faure GC. Morphological alterations of the choroid plexus in late-onset Alzheimer's disease. Acta Neuropathol. 2000;99(2):105-8.

20. Dekaban AS. Changes in brain weights during the span of human life: relation of brain weights to body heights and body weights. Ann Neurol. 1978;4(4):345-56.

21. Hammarlund-Udenaes M, Fridén M, Syvänen S, Gupta A. On the rate and extent of drug delivery to the brain. Pharm Res. 2008;25(8):1737-50

22. Kawakami J, Yamamoto K, Sawada Y, Iga T. Prediction of brain delivery of ofloxacin, a new quinolone, in the human from animal data. J Pharmacokinet Biopharm. 1994;22(3):207-27.

23. Begley DJ, Bradbury MW, Kreuter J. The blood-brain barrier and drug delivery to the CNS. New York: Marcel Dekker, Inc.; 2000.

24. Thorne RG, Hrabe S, Nicholson C, Robert G. Diffusion of epidermal growth factor in rat brain extracellular space measured by integrative optical imaging. J Neurophysiol. 2004;92(6):3471-81.

25. Cserr H, Cooper D, Suri P, Patlak C. Efflux of radiolabeled polyethylene glycols and albumin from rat brain. Am J Physiol. 1981;240(4):319-28.

26. Sakka L, Coll G, Chazal J. Anatomy and physiology of cerebrospinal fluid. Eur Ann Otorhinolaryngol Head Neck Dis. 2011;128(6):309-16.

27. Kimelberg HK. Water homeostasis in the brain: basic concepts. Neuroscience. 2004;129(4):851-60.

28. Pardridge WM. Drug transport in brain via the cerebrospinal fluid. Fluids Barriers CNS. 2011;8(7):1-7.

29. Condon P, Wyper D, Grant R, Patterson J, Hadley D, Teasdale G, et al. Use of magnetic resonance imaging to measure intracranial cerebrospinal fluid volume. Lancet. 1986;327(8494):1355-7.

30. Kohn MI, Tanna NK, Herman GT, Resnick SM, Mozley PD, Gur RE, et al. Analysis of brain and cerebrospinal fluid volumes with MR imaging. part I. methods, reliability, and validation. Radiology. 1991;178(1):115-22.

31. Robertson EG. Developmental defects of the cisterna magna and dura mater. J Neurol Neurosurg Psychiatry. 1949;12(1):39-51.

32. Adam R, Greenberg JO. The mega cisterna magna. J Neurosurg. 1978;48(2):190-2.

33. Bass NH, Lundborg P. Postnatal development of bulk flow in the cerebrospinal fluid system of the albino rat: clearance of carboxyl(14 C)inulin after intrathecal infusion. Brain Res. 1973;52:323-32.

34. Levinger IM. The cerebral ventricles of the rat. J Anat. 1971;108(3):447-51.

35. Stange K, Greitz M, Ingvar T, Hindmarsh T, Sollevi A. Global cerebral blood flow during infusion of adenosine in humans: assessment by magnetic resonance imaging and positron emission tomography. Acta Physiol Scand. 1997;160(2):117-22.

36. Ito $\mathrm{H}$, Inoue $\mathrm{K}$, Goto $\mathrm{R}$, Kinomura $\mathrm{S}$, Taki $\mathrm{Y}$, Okada $\mathrm{K}$, et al. Database of normal human cerebral blood flow measured by SPECT: I. comparison between I-123-IMP, Tc-99m-HMPAO, and Tc-99m-ECD as referred with O-15 labeled water PET and voxel-based morphometry. Ann Nucl Med. 2006;20(2):131-8.

37. Fagerholm U. The highly permeable blood-brain barrier: an evaluation of current opinions about brain uptake capacity. Drug Discov Today. 2007;12(23-24):1076-82.

38. Harashima H, Sawada Y, Sugiyama Y, Iga T, Hanano M. Analysis of nonlinear tissue distribution of quinidine in rats by physiologically based pharmacokinetics. J Pharmacokinet Biopharm. 1985;13(4):425-40. 
39. Peng B, Andrews J, Nestorov I, Brennan B, Nicklin P, Rowland M. Tissue distribution and physiologically based pharmacokinetics of antisense phosphorothioate oligonucleotide ISIS 1082 in rat. Antisense Nucleic Acid Drug Dev. 2001;11(1):15-27.

40. Abbott NJ. Prediction of blood-brain barrier permeation in drug discovery from in vivo, in vitro and in silico models. Drug Discov Today Technol. 2004;1(4):407-16.

41. Abbott NJ. Evidence for bulk flow of brain interstitial fluid: significance for physiology and pathology. Neurochem Int. 2004;45(4):545-52.

42. Skipor J, Thiery JC. The choroid plexus-cerebrospinal fluid system: undervaluated pathway of neuroendocrine signaling into the brain. Acta Neurobiol Exp. 2008;68(3):414-28.

43. Kumar G, Smith QR, Hokari M, Parepally J, Duncan MW. Brain uptake, pharmacokinetics, and tissue distribution in the rat of neurotoxic N-butylbenzenesulfonamide. Toxicol Sci. 2007;97(2):253-64.

44. Strazielle N, Ghersi-Egea JF. Choroid plexus in the central nervous system: biology and physiopathology. J Neuropathol Exp Neurol. 2000;59(7):561-74.

45. Kusuhara H, Sugiyama Y. Active efflux across the blood-brain barrier : role of the solute carrier family. J Am Soc Exp Neurother. 2005;2:73-85.

46. Schinkel AH. P-Glycoprotein, a gatekeeper in the blood-brain barrier. Adv Drug Deliv Rev. 1999;36(2-3):179-94.

47. Tsuji A, Tamai I. Blood-brain barrier function of P-glycoprotein. Adv Drug Deliv Rev. 1997;25(2-3):287-98.

48. Bendayan R. In situ localization of P-glycoprotein (ABCB1) in human and rat brain. J Histochem Cytochem. 2006;54(10):1159-67.

49. Löscher W, Potschka H. Role of drug efflux transporters in the brain for drug disposition and treatment of brain diseases. Prog Neurobiol. 2005;76(1):22-76.

50. Schinkel AH, Jonker JW. Mammalian drug efflux transporters of the ATP binding cassette (ABC) family: an overview. Adv Drug Deliv Rev. 2003;55:3-29.

51. Shapiro AB, Ling V. Stoichiometry of coupling of rhodamine 123 transport to ATP hydrolysis by P - glycoprotein. Eur J Biochem. 1998;254:189-93.

52. Rao VV, Dahlheimer JL, Bardgett ME, Snyder AZ, Finch RA, Sartorelli AC, et al. Choroid plexus epithelial expression of MDR1 P glycoprotein and multidrug resistance-associated protein contribute to the blood-cerebrospinal-fluid drugpermeability barrier. Med Sci. 1999;96(7):3900-5.

53. Cordon-Cardo C, O'Brien JP, Casals D, Rittman-Grauer L, Biedler JL, Melamed MR, et al. Multidrug-resistance gene (Pglycoprotein) is expressed by endothelial cells at blood-brain barrier sites. Proc Natl Acad Sci U S A. 1989;86(2):695-8.

54. Kassem NA, Deane R, Segal MB, Chen R, Preston JE. Thyroxine (T4) transfer from CSF to choroid plexus and ventricular brain regions in rabbit: contributory role of $\mathrm{P}$ glycoprotein and organic anion transporting polypeptides. Brain Res. 2007;1181:44-50.

55. Ronaldson PT, Bendayan M, Gingras D, Piquette-Miller M, Bendayan R. Cellular localization and functional expression of P-glycoprotein in rat astrocyte cultures. J Neurochem. 2004;89(3):788-800.

56. Miller DS. Regulation of ABC transporters at the blood-brain barrier. Clin Pharmacol Ther. 2015;97(4):395-403.

57. Löscher W, Potschka H. Blood-brain barrier active efflux transporters: ATP-binding cassette gene family. NeuroRx. 2005;2(1):86-98.

58. Nies AT, Jedlitschky G, König J, Herold-Mende C, Steiner $\mathrm{HH}$, Schmitt H-P, et al. Expression and immunolocalization of the multidrug resistance proteins, MRP1-MRP6 (ABCC1-ABCC6), in human brain. Neuroscience. 2004;129(2):349-60.

59. Hipfner DR, Deeley RG, Cole SPC. Structural, mechanistic and clinical aspects of MRP1. Biochim Biophys Acta. 1999;1461:359-76.

60. Hirrlinger J, König J, Dringen R. Expression of mRNAs of multidrug resistance proteins (Mrps) in cultured rat astrocytes, oligodendrocytes, microglial cells and neurones. J Neurochem. 2002;82:716-9.
61. Westerhout J, Danhof M, Lange ECMDE. Preclinical prediction of human brain target site concentrations: considerations in extrapolating to the clinical setting. J Pharm Sci. 2011;100(9):3577-93.

62. Begley DJ. ABC transporters and the blood-brain barrier. Curr Pharm Des. 2004;10(12):1295-312.

63. Wijnholds J, De Lange ECM, Scheffer GL, Van Den Berg DD, Mol CAAM, Van Der Valk M. Multidrug resistance protein 1 protects the choroid plexus epithelium and contributes to the blood-cerebrospinal fluid barrier. J Clin Invest. 2000;105(3):279-85.

64. Gao B, Stieger B, Noé B, Fritschy JM, Meier PJ. Localization of the organic anion transporting polypeptide 2 (Oatp2) in capillary endothelium and choroid plexus epithelium of rat brain. J Histochem Cytochem. 1999;47(10):1255-64.

65. Hogue Angeletti R, Novikoff PM, Rao Juvvadi S, Fritschy JM, Meier PJ, Wolkoff AW. The choroid plexus epithelium is the site of the organic anion transport protein in the brain. Neurobiology. 1997;94:283-6.

66. Gao B, Hagenbuch B, Kullak-Ublick GA, Benke D, Aguzzi A, Meier PJ. Organic anion-transporting polypeptides mediate transport of opioid peptides across blood-brain barrier. J Pharmacol Exp Ther. 2000;294(1):73-39.

67. Sekine T, Cha SH, Endou H. The multispecific organic anion transporter (OAT) family. Pflugers Arch. 2000;440(3):337-50.

68. Minn A, Ghersi-Egea J-F, Perrin R, Leininger B, Siest G. Drug metabolizing enzymes in the brain and cerebral microvessels. Brain Res Rev. 1991;16(1):65-82.

69. Miksys SL, Tyndale RF. Drug-metabolizing cytochrome P450s in the brain. J Psychiatry Neurosci. 2002;27(6):406-15.

70. Miksys S, Tyndale RF. Cytochrome P450-mediated drug metabolism in the brain. J Psychiatry Neurosci. 2013;38(3):152-63.

71. Decleves X, Jacob A, Yousif S, Shawahna R, Potin S, Scherrmann J. Interplay of drug metabolizing CYP450 enzymes and $\mathrm{ABC}$ transporters in the blood-brain barrier. Curr Drug Metab. 2011;12(8):732-41.

72. Favetta P, Degoute CS, Perdrix JP, Dufresne C, Boulieu R, Guitton J. Propofol metabolites in man following propofol induction and maintenance. Br J Anaesth. 2002;88(5):653-8.

73. Miksys S, Lerman C, Shields PG, Mash DC, Tyndale RF. Smoking, alcoholism and genetic polymorphisms alter CYP2B6 levels in human brain. Neuropharmacology. 2003;45(1):122-32.

74. Miksys S, Rao Y, Sellers EM, Kwan M, Mendis D, Tyndale RF. Regional and cellular distribution of CYP2D subfamily members in rat brain. Xenobiotica. 2000;30(6):547-64.

75. Zanger UM, Raimundo S, Eichelbaum M. Cytochrome P450 2D6: overview and update on pharmacology, genetics, biochemistry. Naunyn Schmiedebergs Arch Pharmacol. 2004;369(1):23-37.

76. D'empaire I, Guico-Pabia CJ, Preskorn SH. Antidepressant treatment and altered CYP2D6 activity. J Psychiatr Pract. 2011;17(5):330-9.

77. Leysen J, Janssen P, Megens A, Schotte A. Risperidone: a novel antipsychotic with balanced serotonin-dopamine antagonism, receptor occupancy profile, and pharmacologic activity. J Clin Psychiatry. 1994;55:5-12.

78. Matsumoto M, Weickert CS, Beltaifa S, Kolachana B, Chen J, Hyde TM, et al. Catechol O-methyltransferase (COMT) mRNA expression in the dorsolateral prefrontal cortex of patients with schizophrenia. Neuropsychopharmacology. 2003;28(8):1521-30.

79. Huotari M, Gogos JA, Karayiorgou M, Koponen O, Forsberg M, Raasmaja A. Brain catecholamine metabolism in catecholO-methyltransferase (COMT)-de ${ }^{\circledR}$ cient mice. Neuroscience. 2002;15:246-56.

80. Pintar JE, Breakefield XO. Monoamine oxidase (MAO) activity as a determinant in human neurophysiology. Behav Genet. 1982;12(1):53-68.

81. Bogdanski DF, Weissbach H, Udenfriend S. THe distribution of serotonin, 5-hydroxytryptophan decarboxylase, and monoamine oxjdase in brain. J Neurochem. 1957;1:272-8.

82. Luine VN, Khylchevskaya RI, Mcewen BS. Effect of gonadal steroids on activities of monoamine oxidase and choline acetylase in rat brain. Brain Res. 1975;86:293-306. 
83. Robinson DS, Davis JM, Nies A, Ravaris CL, Sylwester D, Burlington V. Relation of sex and aging to monoamine oxidase activity of human brain, plasma, and platelets. Arch Gen Psychiat. 1971;24:536-9.

84. Nagatsu T. Progress in Monoamine Oxidase (MAO) research in relation to genetic engineering. Neurotoxicology. 2004;25(12):11-20.

85. Levitt P, Pintart JE, Breakefieldt XO. Immunocytochemical demonstration of monoamine oxidase $\mathrm{B}$ in brain astrocytes and serotonergic neurons (central nervous system/rat/monoamine). Neurobiology. 1982;79:6385-9.

86. Ohno S, Kawana K, Nakajin S. Contribution of UDPglucuronosyltransferase $1 \mathrm{~A} 1$ and $1 \mathrm{~A} 8$ to morphine-6glucuronidation and its kinetic properties. Drug Metab Dispos. 2008;36(4):688-94.

87. Ghersi-Egea JF, Leninger-Muller B, Suleman G, Siest G, Minn A. Localization of drug-metabolizing enzyme activities to blood-brain interfaces and circumventricular organs. J Neurochem. 1994:62:1089-96.

88. King CD, Rios GR, Assouline JA, Tephly TR. Expression of UDP-Glucuronosyltransferases (UGTs) $2 \mathrm{~B} 7$ and $1 \mathrm{~A} 6$ in the human brain and identification of 5-hydroxytryptamine as a substrate. Arch Biochem Biophys. 1999;365(1):156-62.

89. Suleman FG, Abid A, Gradinaru D, Daval J-L, Magdalou J, Minn A. Identification of the uridine diphosphate glucuronosyltransferase isoform UGT1A6 in rat brain and in primary cultures of neurons and astrocytes. Arch Biochem Biophys. 1998;358(1):63-7.

90. Foldes A, Meek JL. Rat brain phenolsulfotransferase-partial purification and some properties. Biochim Biophys Acta 1973. 1973;327:365-74.

91. Meek JL, Neff NH. Biogenic amines and their metabolites as substrates for phenol sulphotransferase (EC 2.8.2.1) of brain and liver. J Neurochem. 1973;21(9):1-9.

92. Renskers KJ, Feor KD, Roth JA. Sulfation of dopamine and other biogenic amines by human brain phenol sulfotransferase. J Neurochem. 1980;34(6):1362-8.

93. Levin VA. Relationship of octanol/water partition coefficient and molecular weight to rat brain capillary permeability. J Med Chem. 1980;23:682-4.

94. Van de Waterbeernd er al $\mathrm{H}$, van de Waterbeemd $\mathrm{H}$, Camenisch G, Folkers G, Raevsky OA. Estimation of Caco-2 cell permeability using calculated molecular descriptors. Quant Struct-Act Relat. 1996;15:480-90.

95. Lipinski CA, Lombardo F, Dominy BW, Feeney PJ. Experimental and computational approaches to estimate solubility and permeability in drug discovery and development settings. Adv Drug Deliv Rev. 2012;64:4-17.

96. Chan OH, Stewart BH. Physicochemical and drug- delivery considerations for oral drug bioavailability. Drug Discov Today. 1996;1(11):461-73.

97. Upton RN. Regional pharmacokinetics I. Physiological and physicochemical basis. Biopharm Drug Dispos. 1990;11(8):647-62.

98. Shayanfar A, Soltani S, Jouyban A. Prediction of blood-brain distribution: effect of ionization. Biol Pharm Bull. 2011;34(2):26671.

99. Macintyre AC, Cutler DJ. The potential role of lysosomes in tissue distribution of weak bases. Biopharm Drug Dispos. 1988;9:513-26.

100. Fridén M, Winiwarter S, Jerndal G, Bengtsson O, Wan H, Bredberg U, et al. Structure-brain exposure relationships in rat and human using a novel data set of unbound drug concentrations in brain interstitial and cerebrospinal fluids. J Med Chem. 2009;52(20):6233-43.

101. Palm K, Luthman K, Ungell AL, Strandlund G, Beigi F, Lundahl P. Evaluation of dynamic polar molecular surface area as predictor of drug absorption: comparison with other computational and experimental predictors. J Med Chem. 1998;41(27):5382-92.

102. Krarup LH, Christensen thager I, Hovgaad L, Frokjaer S. Predicting drug absorption from molecular surface properties based on molecular dynamics simulations. Pharmacetical Res. 1998;15(7):972-8.

103. Loryan I, Sinha V, Mackie C, Van Peer A, Drinkenburg WH, Vermeulen A, et al. Molecular properties determining unbound intracellular and extracellular brain exposure of CNS drug candidates. Mol Pharm. 2015;12(2):520-32.

104. Peletier LA, Benson N, van der Graaf PH. Impact of plasmaprotein binding on receptor occupancy: an analytical description. J Theor Biol. 2009;256(2):253-62.

105. Abbott NJ, Rönnbäck L, Hansson E. Astrocyte-endothelial interactions at the blood-brain barrier. Nat Rev Neurosci. 2006; 7(41-53).

106. Lee G, Dallas S, Hong M, Bendayan R. Drug transporters in the central nervous system: brain barriers and brain parenchyma considerations. Pharmacol Rev. 2001;53(4):56996.

107. Ohtsuki S, Terasaki T. Contribution of carrier-mediated transport systems to the blood-brain barrier as a supporting and protecting interface for the brain; importance for CNS drug discovery and development. Pharm Res. 2007;24(9):1745-58.

108. Plassat R, Verbe BP, Menei P, Menegalli D, Mathe JIR. Treatment of spasticity with intrathecal Baclofen administration long-term follow-up, review of 40 patients. Spinal Cord. 2004;42:686-93.

109. Kroin JS. The distribution of medication along the spinal canal after chronic intrathecal administration. Neurosurgery. 1993;33:226-30.

110. Hettiarachchi HDM, Hsu Y, Harris TJ, Penn R, Linninger A. a. The effect of pulsatile flow on intrathecal drug delivery in the spinal canal. Ann Biomed Eng. 2011:39(10):2592-602.

111. Hsu Y, Hettiarachchi HDM, Zhu DC, Linninger AA. The frequency and magnitude of cerebrospinal fluid pulsations influence intrathecal drug distribution. Anesth Analg. 2012;115(2):386-94.

112. Pardridge WM. $\log (\mathrm{BB})$, PS products and in silico models of drug brain penetration. Drug Discov Today. 2004;9(9):392-3.

113. Chen H, Winiwarter S, Fridén M, Antonsson M, Engkvist O. In silico prediction of unbound brain-to-plasma concentration ratio using machine learning algorithms. J Mol Graph Model. 2011;29(8):985-95.

114. Loryan I, Fridén M, Hammarlund-Udenaes M. The brain slice method for studying drug distribution in the CNS. Fluids Barriers CNS. 2013;10(6):1-9.

115. Helms HC, Abbott NJ, Burek M, Cecchelli R, Couraud P-O, Deli MA, et al. In vitro models of the blood-brain barrier: an overview of commonly used brain endothelial cell culture models and guidelines for their use. J Cereb Blood Flow Metab. 2016;36(5):862-90.

116. Bicker J, Alves G, Fortuna A, Falcão A. Blood-brain barrier models and their relevance for a successful development of CNS drug delivery systems: a review. Eur J Pharm Biopharm. 2014;87(3):409-32.

117. Bernas MJ, Cardoso FL, Daley SK, Weinand ME, Campos AR, Ferreira AJG, et al. Establishment of primary cultures of human brain microvascular endothelial cells to provide an in vitro cellular model of the blood-brain barrier. Nat Protoc. 2010;5(7):1265-72.

118. Weksler BB, Subileau EA, Perrière N, Charneau P, Holloway $\mathrm{K}$, Leveque $\mathrm{M}$. Blood-brain barrier-specific properties of a human adult brain endothelial cell line. FASEB J. 2005;19(13):1872-4.

119. Cecchelli R, Aday S, Sevin E, Almeida C, Culot M, Dehouck $\mathrm{L}$, et al. A stable and reproducible human blood-brain barrier model derived from hematopoietic stem cells. PLoS One. 2014;9(6):1-11.

120. Stanimirovic DB, Bani-Yaghoub M, Perkins M, Haqqani AS. Blood-brain barrier models: in vitro to in vivo translation in preclinical development of CNS-targeting biotherapeutics. Expert Opin Drug Discov. 2015;10(2):141-55.

121. Larregieu CA, Benet LZ. Distinguishing between the permeability relationships with absorption and metabolism to improve BCS and BDDCS predictions in early drug discovery. Mol Pharm. 2014;11(4):1335-44.

122. Broccatelli F, Larregieu CA, Cruciani G, Oprea TI, Benet LZ. Improving the prediction of the brain disposition for orally administered drugs using BDDCS. Adv Drug Deliv Rev. 2012;64(1):95-109.

123. Kikuchi R, De Morais SM, Kalvass JC. In vitro P-glycoprotein efflux ratio can predict the in vivo brain penetration regardless 
of biopharmaceutics drug disposition classification system class. Drug Metab Dispos. 2013;41(12):2012-7.

124. Kalvass JC, Maurer TS. Influence of nonspecific brain and plasma binding on CNS exposure: implications for rational drug discovery. Biopharm Drug Dispos. 2002;23(8):327-38.

125. Friden M, Gupta A, Antonsson M, Bredberg U, HammarlundUdenaes $M$. In vitro methods for estimating unbound drug concentrations in the brain interstitial and intracellular fluids. Drug Metab Dispos. 2007;35:1711-9.

126. Hammarlund-Udenaes M, Paalzow LK, De Lange ECM. Drug equilibration across the blood-brain barrier-pharmacokinetic considerations based on the microdialysis method. Pharm Res. 1997;14(2):128-34.

127. Hammarlund-Udenaes M. The use of microdialysis in CNS drug delivery studies: pharmacokinetic perspectives and results with analgesics and antiepileptics. Adv Drug Deliv Rev. 2000;45(2-3):283-94.

128. Elmquist W, Sawchuk R. Application of microdialysis in pharmacokinetic studies. Pharm Res. 1997;14(3):267-88.

129. de Lange EC, Danhof $M$, de Boer AG, Breimer DD. Methodological considerations of intracerebral microdialysis in pharmacokinetic studies on drug transport across the bloodbrain barrier. Brain Res Brain Res Rev. 1997;25(1):27-49.

130. Westerhout J, Smeets J, Meindert D, De Lange ECM. The impact of P-gp functionality on non-steady state relationships between CSF and brain extracellular fluid. J Pharmacokinet Pharmacodyn. 2013;40(3):327-42.

131. Neuwelt E, Abbott NJ, Abrey L, Banks WA, Blakley B, Davis $\mathrm{T}$, et al. Strategies to advance translational research into brain barriers. Lancet Neurol. 2008;7(1):84-96.

132. Assmus F, Seelig A, Gobbi L, Borroni E, Glaentzlin P, Fischer $\mathrm{H}$. Label-free assay for the assessment of nonspecific binding of positron emission tomography tracer candidates. Eur J Pharm Sci. 2015;79:22-35.

133. Loryan I, Sinha V, Mackie C, Van Peer A, Drinkenburg W, Vermeulen A, et al. Mechanistic understanding of brain drug disposition to optimize the selection of potential neurotherapeutics in drug discovery. Pharm Res. 2014;32(8):2203-19.

134. Loryan I, Melander E, Svensson M, Payan M, König F, Jansson B, et al. In-depth neuropharmacokinetic analysis of antipsychotics based on a novel approach to estimate unbound target-site concentration in CNS regions: link to spatial receptor occupancy. Mol Psychiatry. 2016; 1-10.

135. Murbach Freire C, Marques M, Costa M. Effects of seasonal variation on the central nervous system activity of Ocimum gratissimum L. essential oil. J Ethnopharmacol. 2006;105:161-6.

136. Bowie MW, Slattum PW. Pharmacodynamics in older adults: a review. Am J Geriatr Pharmacother. 2007;5(3):263-303.

137. Bigos KL, Pollock BG, Stankevich BA, Bies RR. Sex differences in the pharmacokinetics and pharmacodynamics of antidepressants: an updated review. Gend Med. 2009;6(4):522-43.

138. Oksenberg D, Marsters S, O'Dowd B, Jin H. A single aminoacid difference confers major pharmacological variation between human and rodent 5-HT1B receptors. Nature. 1992;360:161-3.

139. Grandison MK, Boudinot FD. Age-related changes in protein binding of drugs: implications for therapy. Clin Pharmacokinet. 2000;38(3):271-90.

140. Greenblatt D. Reduced serum albumin concentration in the elderly: a report from the Boston Collaborative Drug Surveillance Program. J Am Geriatr Soc. 1979;27(1):20-2.

141. Piafsky KM, Borgå O, Odar-Cederlöf I, Johansson C, Sjöqvist F. Increased plasma protein binding of propranolol and chlorpromazine mediated by disease-induced elevations of plasma $\alpha 1$ acid glycoprotein. New Engl J Med. 1978;2(99):1435-9.

142. Shaw TG, Mortel KF, Meyer JS, Rogers RL, Hardenberg J, Cutaia MM. Cerebral blood flow changes in benign aging and cerebrovascular disease. Neurology. 1984;34(7):855.

143. Kim SG. Quantification of relative cerebral blood-flow change by flow-sensitive alternating inversion-recovery (fair) technique - application to functional mapping. Magn Reson Med. 1995;34(3):293-301.

144. Braun AR, Balkin TJ, Wesensten NJ, Carson RE, Varga M, Baldwin P, et al. Regional cerebral blood flow throughout the sleep-wake cycle An H 215 O PET study. Brain. 1997;120:1173-97.
145. Giusto NM, Salvador GA, Castagnet PI, Pasquaré SJ, de Boschero Ilincheta MG. Age-associated changes in central nervous system glycerolipid composition and metabolism. Neurochem Res. 2002;27(11):1513-23.

146. Yehuda S, Rabinovitz S, Carasso RL, Mostofsky DI. The role of polyunsaturated fatty acids in restoring the aging neuronal membrane. Neurobiol Aging. 2002;23:843-53.

147. Uauy R, Dangour AD. Nutrition in brain development and aging: role of essential fatty acids. Nutr Rev. 2006;64(5):24-33.

148. Yehuda S, Rabinovitz S, Mostofsky DI. Essential fatty acids and the brain: from infancy to aging. Neurobiol Aging. 2005;26:98-102.

149. Assies J, Lieverse R, Vreken P, Wanders RJ, Dingemans PMJ, Linszen DH. Significantly reduced docosahexaenoic and docosapentaenoic acid concentrations in erythrocyte membranes from schizophrenic patients compared with a carefully matched control group. Biol Psychiatry. 2001;49(6):510-22.

150. Mark KS, Davis TP. Cerebral microvascular changes in permeability and tight junctions induced by hypoxia-reoxygenation. Am J Physiol Heart Circ Physiol. 2002;282(4):1485-94.

151. Sandoval KE, Witt KA. Blood-brain barrier tight junction permeability and ischemic stroke. Neurobiol Dis. 2008;32(2):20019.

152. Marco S, Skaper SD. Amyloid beta-peptide1-42 alters tight junction protein distribution and expression in brain microvessel endothelial cells. Neurosci Lett. 2006;401:219-24.

153. Plumb J, McQuaid S, Mirakhur M, Kirk J. Abnormal endothelial tight junctions in active lesions and normal-appearing white matter in multiple sclerosis. Brain Pathol. 2002;12:154-69.

154. Blomqvisp G, Hospital K, Brain M. Facilitated transport of glucose from blood to brain in man on cerebral glucose utilization. Eur J Nucl Med. 1991;18:834-7.

155. Miyagawa T, Oku T, Uehara H, Desai R, Beattie B, Tjuvajev J, et al. "Facilitated" amino acid transport is upregulated in brain tumors. J Cereb Blood Flow Metab. 1998;18(5):500-9.

156. Claudio L, Kress Y, Norton WT, Brosnan CF. Increased vesicular transport and decreased mitochondrial content in blood-brain barrier endothelial cells during experimental autoimmune encephalomyelitis. Am J Pathol. 1989;135(6):1157-68.

157. Reulen HJ, Graham R, Spatz M, Klatzo I. Role of pressure gradients and bulk flow in dynamics of vasogenic brain edema. J Neurosurg. 1977;46(1):24-35.

158. Resnick SM, Pham DL, Kraut MA, Zonderman AB, Davatzikos C. Longitudinal magnetic resonance imaging studies of older adults: a shrinking brain. J Neurosci. 2003;23(8):3295-301.

159. Serot JM, Béné MC, Foliguet B, Faure GC. Altered choroid plexus basement membrane and epithelium in late-onset Alzheimer's disease: an ultrastructural study. Ann N Y Acad Sci. 1997;826:507-9.

160. May C, Kaye JA, Atack JR, Schapiro MB, Friedland RP, Rapoport SI. Cerebrospinal fluid production is reduced in healthy aging. Neurology. 1990;40:500-3.

161. Silverberg GD, Mayo M, Saul T, Rubenstein E, Mcguire D. Alzheimer' s disease, normal-pressure hydrocephalus, and senescent changes in CSF circulatory physiology : a hypothesis. Lancet Neurol. 2003;2:506-11.

162. Johanson CE, Duncan JA, Klinge PM, Brinker T, Stopa EG, Silverberg GD. Multiplicity of cerebrospinal fluid functions: new challenges in health and disease. Cerebrospinal Fluid Res. 2008;5(10):1-32.

163. Mann A, Miksys SL, Gaedigk A, Kish SJ, Mash DC, Tyndale RF. The neuroprotective enzyme CYP2D6 increases in the brain with age and is lower in Parkinson's disease patients. Neurobiol Aging. 2012;33(9):2160-71.

164. Oreland L, Gottfries C-G. Brain and brain monoamine oxidase in aging and in dementia of Alzheimer's type. Prog NeuroPsychopharmacol Biol Psychiatr. 1986;10:533-40.

165. Chen J, Lipska BK, Halim N, Ma QD, Matsumoto M, Melhem S, et al. Functional analysis of genetic variation in Catechol-OMethyltransferase (COMT): effects on mRNA, protein, and enzyme activity in postmortem human brain. Am J Hum Genet. 2004;75:807-21.

166. Meyer-Lindenberg A, Nichols T, Callicott JH, Ding J, Kolachana B, Buckholtz J, et al. Impact of complex genetic 
variation in COMT on human brain function. Mol Psychiatry. 2006;11(9):867-77.

167. Howard LA, Miksys S, Hoffmann E, Mash D, Tyndale RF. Brain CYP2E1 is induced by nicotine and ethanol in rat and is higher in smokers and alcoholics. Br J Pharmacol. 2003;138(7):1376-86.

168. Toornvliet R, van Berckel BNM, Luurtsema G, Lubberink M, Geldof AA, Bosch TM. Effect of age on functional Pglycoprotein in the blood-brain barrier measured by use of (R)-[(11)C]verapamil and positron emission tomography. Clin Pharmacol Ther. 2006;79(6):540-8.

169. Vorbrodt A, Dobrogowska D, Meeker H, CARP R. Immunogold study of regional differences in the distribution of glucose transporter (GLUT-1) in mouse brain associated with physiological and accelerated aging and scrapie infection. J Neurocytol. 1999;28:711-9.

170. Aronica E, Gorter JA, Jansen GH, van Veelen CW, van Rijen PC, Leenstra S, et al. Expression and cellular distribution of multidrug transporter proteins in two major causes of medically intractable epilepsy: focal cortical dysplasia and glioneuronal tumors. Neuroscience. 2003;118(2):417-29.

171. Spiegl-Kreinecker S, Buchroithner J, Elbling L, Steiner E, Wurm G, Bodenteich A, et al. Expression and functional activity of the $\mathrm{ABC}$-transporter proteins P-glycoprotein and multidrug-resistance protein 1 in human brain tumor cells and astrocytes. J Neurooncol. 2002;57(1):27-36.

172. Danbolt NC. Glutamate uptake. Prog Neurobiol. 2001;65(1):1-105.

173. Holmes GL. Seizure-induced neuronal injury. Neurology. 2002;59(9):3-6.

174. Kervezee L, Hartman R, van den Berg D-J, Shimizu S, EmotoYamamoto $\mathrm{Y}$, Meijer JH, et al. Diurnal variation in $\mathrm{P}$ glycoprotein-mediated transport and cerebrospinal fluid turnover in the brain. AAPS J. 2014;16(5):1029-37.

175. Collins JM, Dedrick RL. Distributed model for drug delivery to CSF and brain tissue. Am J Physiol. 1983;245(3):303-10.

176. Ooie T, Terasaki T, Suzuki H, Sugiyama Y. Kinetic evidence for active efflux transport across the blood-brain barrier of quinolone antibiotics. J Pharmacol Exp Ther. 1997;283(1):293-304.

177. Takasawa K, Terasaki T, Suzuki H, Ooie T, Sugiyama Y. Distributed model analysis of $3^{\prime}$-azido-3'-deoxythymidine and $2^{\prime}, 3^{\prime}$-dideoxyinosine distribution in brain tissue and cerebrospinal fluid. J Pharmacol Exp Ther. 1997;282(3):1509-17.

178. Hansen DK, Scott DO, Otis KW, Lunte SM. Comparison of in vitro BBMEC permeability and in vivo CNS uptake by microdialysis sampling. J Pharm Biomed Anal. 2002;27:945-58.

179. Bourasset F, Scherrmann JM. Carrier-mediated processes at several rat brain interfaces determine the neuropharmacokinetics of morphine and morphine-6-beta-D-glucuronide. Life Sci. 2006;78(20):2302-14.

180. Liu X, Smith BJ, Chen C, Callegari E, Becker SL, Chen X, et al. Use of a physiologically based pharmacokinetic model to study the time to reach brain equilibrium: an experimental analysis of the role of blood-brain barrier permeability, plasma protein binding, and brain tissue binding. J Pharmacol Exp Ther. 2005;313(3):1254-62.
181. Kielbasa W, Stratford RE. Exploratory translational modeling approach in drug development to predict human brain pharmacokinetics and pharmacologically relevant clinical doses. Drug Metab Dispos. 2012;40(5):877-83.

182. Fenneteau F, Turgeon J, Couture L, Michaud V, Li J, Nekka F. Assessing drug distribution in tissues expressing P-glycoprotein through physiologically based pharmacokinetic modeling: model structure and parameters determination. Theor Biol Med Model. 2009;36:495-522.

183. Ball K, Bouzom F, Scherrmann J-M, Walther B, Declèves X. Physiologically based pharmacokinetic modelling of drug penetration across the blood-brain barrier-towards a mechanistic IVIVE-based approach. AAPS. 2013;15(4): 913-32.

184. Badhan RKS, Chenel M, Penny JI. Development of a physiologically-based pharmacokinetic model of the rat central nervous system. Pharmaceutics. 2014;6(1):97-136.

185. Stevens J, Ploeger BA, Van Der Graaf PH, Danhof M, De Lange ECM. Systemic and direct nose-to-brain transport pharmacokinetic model for remoxipride after intravenous and intranasal administration. Drug Metab Dispos. 2011;39(12):2275-82.

186. de Witte WEA, Danhof M, van der Graaf PH, de Lange ECM. In vivo target residence time and kinetic selectivity: the association rate constant as determinant. Trends Pharmacol Sci. 2016;37(10):831-42.

187. Wagner C, Zhao P, Pan Y, Hsu V, Grillo J, Huang SM, et al. Application of physiologically based pharmacokinetic (PBPK) modeling to support dose selection: report of an FDA Public Workshop on PBPK. Clin Pharmacol Ther. 2015;4(4):226-30.

188. Shepard T, Scott G, Cole S, Nordmark A, Bouzom F. Physiologically based models in regulatory submissions: output from the ABPI/MHRA forum on physiologically based modeling and simulation. CPT Pharmacometrics Syst Pharmacol. 2015;4:221-5.

189. European Medicines Agency. Concept paper on qualification and reporting of physiologically-based pharmacokinetic (PBPK) modelling and analyses. 2014;EMA/CHMP/2. Available from: http://www.ema.europa.eu/docs/en GB/ document_library/Scientific_guideline/2014/06/ WC500169452.pdf.

190. Erdő F, Denes L, de Lange ECM. Age-associated physiological and pathological changes at the blood-brain barrier. J Cereb Blood Flow Metab. 2017;37(1):4-24.

191. Kilkenny C, Browne W, Cuthill IC, Emerson M, Altman DG. Animal research: reporting in vivo experiments: the ARRIVE guidelines. J Gene Med. 2010;12(8):561-3.

192. de Witte WEA, Wong YC, Nederpelt I, Heitman LH, Danhof $\mathrm{M}$, van der Graaf PH, et al. Mechanistic models enable the rational use of in vitro drug-target binding kinetics for better drug effects in patients. Expert Opin Drug Discov. 2016;11(1):45-63. 